\title{
Techno-economic analysis of low-carbon hydrogen production by sorption enhanced steam methane reforming (SE-SMR) processes
}

\author{
Yongliang Yan, Vasilije Manovic, Edward J. Anthony, Peter T. Clough* \\ Energy and Power Theme, School of Water, Energy and Environment, Cranfield University, Cranfield, \\ Bedfordshire, MK43 0AL, UK. \\ * Corresponding author: Peter T. Clough, Email: P.T.Clough@ cranfield.ac.uk, Phone: +44(0)1234 754873
}

\begin{abstract}
Hydrogen is an attractive energy carrier that will play a key role in future global energy transitions. This work investigates the techno-economic performance of six different sorption enhanced steam methane reforming (SE-SMR) configurations integrated with an indirect natural gas or biomass-fired calciner, oxyfuel combustion and chemical-looping combustion for large-scale blue and carbon-negative hydrogen production. The techno-economic performance of the proposed cases were evaluated by their net efficiency, $\mathrm{CO}_{2}$ capture efficiency, levelised cost of hydrogen ( $\left.\mathrm{LCOH}\right)$, and costs of $\mathrm{CO}_{2}$ avoided and removal. A sensitivity analysis was also conducted to evaluate the key parameters and explore existing uncertainties that can affect the economic performance of the proposed SE-SMR processes. The results revealed that the proposed systems were comparable with conventional steam methane reforming (SMR) with carbon capture and storage (CCS). The LCOH of the proposed SE-SMR plants ranged from $£ 1.90-2.80 / \mathrm{kg}$, and the costs of $\mathrm{CO}_{2}$ avoided and removal ranged from $£ 33-69 /$ tonne and $£ 58-107 /$ tonne, respectively. By applying a carbon price ( $£ 16 /$ tonne $\mathrm{CO}_{2}$ ), the costs of $\mathrm{CO}_{2}$ avoided and removal for the proposed SE-SMR processes could be significantly reduced. The results of cumulative discounted cash flow of SE-SMR plants at a hydrogen selling price of $£ 3.00 / \mathrm{kg}$ indicated that all the investment of the proposed cases could be paid back after eight years, even if the carbon tax is zero.
\end{abstract}




\section{Keywords}

Blue hydrogen production, Sorption enhanced steam methane reforming, Carbon capture, Technoeconomic analysis

\section{Highlights}

- The economics of retrofitted sorption enhanced steam methane reforming is investigated.

- The levelised cost of $\mathrm{H}_{2}$ ranges from $£ 1.90-2.80 / \mathrm{kg}$.

- The cost of $\mathrm{CO}_{2}$ avoided ranges from $£ 33-69 /$ tonne $\mathrm{CO}_{2}$.

- The results provide flexible options for blue and carbon-negative $\mathrm{H}_{2}$ production.
Abbreviations
ATR+GHR Autothermal reforming with gas heated reformer
AR
Air reactor
ASU
Air separation unit
CCA
Cost of $\mathrm{CO}_{2}$ avoided
CCR
Cost of $\mathrm{CO}_{2}$ removal
CCS Carbon capture and storage
CEPCI Chemical engineering plant cost index
CF Capacity factor
CLC Chemical-looping combustion
CLR Chemical-looping reforming
FC Fuel costs
FCF $\quad$ Fixed charge factor
FOM Fixed operating and maintenance costs
FR Fuel reactor 
HR

HRSG Heat recovery steam generator

$\mathrm{LCOH} \quad$ Levelised cost of hydrogen

LHV

MDEA

MEA

$\mathrm{NCF}_{\mathrm{n}}$

NPV

PSA

PSAOG

SMR

SE-SMR

TDCC

TEA

TRL

TOC

VOM
Heat rate

Lower heating value

Methyldiethanolamine

Monoethanolamine

Net cash flow in year $\mathrm{n}$

Net present value

Pressure swing adsorption

Pressure swing adsorption off gas

Steam methane reforming

Sorption enhanced steam methane reforming

Total direct capital cost

Triethanolamine

Technology readiness level

Total overnight capital costs

Variable operating and maintenance costs 


\section{Introduction}

Hydrogen is a versatile feedstock that is widely used in oil refining, ammonia synthesis and the production of many other chemicals. Using low-carbon hydrogen as an energy carrier is attracting increasing attention due to its potential to replace carbon-intensive fossil fuels, which enables end-users to solve critical decarbonisation related issues in the transport, residential, and power sectors. Globally, approximately 70 Mt of dedicated hydrogen was produced in 2019, 76\% from natural gas, 23\% from coal and the rest from oil and electricity, which resulted in the emission of approx. $830 \mathrm{Mt} \mathrm{CO}_{2}\left(2.6 \%\right.$ of global $\mathrm{CO}_{2}$ emissions in 2019)[1]. Looking at the annual $\mathrm{CO}_{2}$ emissions from hydrogen production in 2014 (550 Mt), it has increased by $51 \%$ points in 2019 . Moreover, if hydrogen is mainly produced from natural gas and coal without employing carbon capture and storage (CCS) technologies, then $\mathrm{CO}_{2}$ emissions from hydrogen production will increase significantly with the rapid growth rate of $\mathrm{H}_{2}$ demand. Despite efforts to drive down the costs of green hydrogen production by solar, wind and biomass energy, natural gas reforming remains the most economic pathway for large-scale hydrogen production in the foreseeable future. Therefore, there is an urgent need to develop low-carbon hydrogen production technologies that enable us to use hydrogen in the energy transition while achieving the $2{ }^{\circ} \mathrm{C}$ Paris Agreement goal and mitigating further climate change.

To reduce the $\mathrm{CO}_{2}$ emissions of hydrogen production by Steam Methane Reforming (SMR), Autothermal Reforming (ATR) with gas heated reformer (GHR), coal and biomass gasification, different options such as adsorption, absorption, membranes and cryogenic separation can be adopted. Detailed reviews of different hydrogen production technologies integrated with $\mathrm{CO}_{2}$ capture are available in the literature [25]. Among them, one novel and promising technology is sorption enhanced steam methane reforming (SESMR), which can produce low-carbon and high purity $\mathrm{H}_{2}$ through an in-situ $\mathrm{CO}_{2}$ capture process where the hydrocarbon fuel is reacted with steam in the presence of a $\mathrm{CO}_{2}$ sorbent and a reforming catalyst. Compared to the current available SMR technologies with aqueous solutions of amines such as MEA, TEA and MDEA for decarbonised hydrogen production, the SE-SMR approach has the advantages of high yields of $\mathrm{H}_{2}$, high conversion of methane, low reforming temperature, without the requirement of multiple shift reactors and subsequent purification steps. Recently, extensive research has been carried out to develop highperformance $\mathrm{CO}_{2}$ sorbents for multiple SE-SMR/regeneration cycles [6-12], and to investigate the thermodynamic performance of different integrations of SE-SMR process for hydrogen production [1318]. The main drawback of the SE-SMR technology is that to produce the calcination heat demand without emitting $\mathrm{CO}_{2}$ to the atmosphere requires energy-intensive processes like oxy-fuel combustion or the use of an indirectly heated calciner.

To reduce the energy penalties and $\mathrm{CO}_{2}$ emissions from the regeneration of $\mathrm{CO}_{2}$ sorbent during the SESMR process, different integrations have been proposed for decarbonised and high-purity hydrogen 
production. Ochoa-Fernández et al. [13] investigated the process simulation performance of SE-SMR integrated with oxy-fuel combustion with $\mathrm{CaO}$ and other novel $\mathrm{CO}_{2}$ acceptors $\left(\mathrm{Li}_{2} \mathrm{ZrO}_{3}, \mathrm{~K}\right.$-doped $\mathrm{Li}_{2} \mathrm{ZrO}_{3}$, $\mathrm{Na}_{2} \mathrm{ZrO}_{3}$ and $\mathrm{LiSiO}_{4}$ ). Their results indicated that the use of $\mathrm{CaO}$ as the $\mathrm{CO}_{2}$ acceptor integrated with oxyfuel combustion had better performance in terms of net efficiency, $\mathrm{CO}_{2}$ capture efficiency, and required smaller pressure swing adsorption (PSA) unit for hydrogen purification compared to that of SMR with MEA. Abanades et al. [16] proposed the integrated $\mathrm{Ca}-\mathrm{Cu}$ looping process for hydrogen production, which utilised the heat of reduction of $\mathrm{CuO}$ with a fuel gas for calcination of $\mathrm{CaCO}_{3}$. Later on, this concept was further investigated by means of experiments and process simulations[19-21].

Besides applying the oxy-fuel combustion and $\mathrm{Ca}-\mathrm{Cu}$ looping for calcination of $\mathrm{CaCO}_{3}$, indirectly heated calcination process through the use of heat pipes and heat transfer walls has been intensively investigated [22-24] and successfully demonstrated with a $300 \mathrm{kWth}$ carbonate looping pilot. Zhu et al. [14] proposed a novel SE-SMR process thermally coupled with chemical-looping combustion (CLC) to supply the necessary heat for calcination of $\mathrm{CaCO}_{3}$. The results of thermodynamic analysis showed that the overall exergy efficiency of SE-SMR integrated with CLC increased by $14.39 \%$ points compared to SMR without CCS. Yan et al. [18] evaluated the process performance of different SE-SMR configurations, which consisted of process integrations with PSA, CLC, oxy-fuel combustion or $\mathrm{H}_{2}$-fired calciner, and their results indicated that the upgraded SE-SMR processes could provide flexible options for low-carbon hydrogen production based on the costs and demand of $\mathrm{CO}_{2}$ reduction.

Although, different SE-SMR configurations have given promising results in experimental investigations and by thermodynamic analysis, there is a limited work on economic assessment to fully understand the potential of SE-SMR at large scales. Diglio et al. conducted a techno-economic assessment of SE-SMR in a fixed bed reactor network integrated with fuel cells and calculated the cost of $\mathrm{CO}_{2}$ avoided was $£ 33.43 / \mathrm{kg}$ $\mathrm{CO}_{2}$, which was lower than that of SMR with $\mathrm{CO}_{2}$ capture and chemical-looping reforming (CLR). However, there is no further published work on the economic performance of SE-SMR or SE-SMR integrated with other process options to achieve near-zero and negative $\mathrm{CO}_{2}$ emissions (oxy-fuel combustion, chemical-looping combustion or biomass-fired calciner).

A series of studies have been conducted to evaluate the economic performance of current and emerging technologies for low-carbon hydrogen production such as SMR with amine scrubbing [25], SMR with CLC [26], ATR with CCS [26], CLR [25-27], membrane assisted fluidised-bed reactors [28] and gas switching reforming [29], and the levelised cost of hydrogen ( $\mathrm{LCOH})$ of these technologies was reported to be in the range of $£ 1.42-2.84 / \mathrm{kg} \mathrm{H}_{2}$. To compare the economic performance of SE-SMR with the above low-carbon hydrogen production technologies and promote the scale-up of the SE-SMR technology, techno-economic assessments of various SE-SMR configurations for hydrogen production are required. 
The objectives of this study are to evaluate the techno-economic feasibility of the SE-SMR process integrated with oxy-fuel combustion, chemical-looping combustion and biomass-fired calciner for lowcarbon (blue) and carbon-negative hydrogen production. The operating and economic performance of the proposed cases is evaluated in terms of the net efficiency, $\mathrm{CO}_{2}$ capture efficiency, $\mathrm{LCOH}, \mathrm{CO}_{2}$ avoided and removal cost, and is compared with that of SMR and CLR with CCS. Besides, a detailed sensitivity analysis is performed to explore the influence of uncertainty in the input variables on the key economic performance indicators.

\section{Methodology}

\subsection{Process description of different SE-SMR configurations}

In our previous work [18], we have investigated the thermodynamic performance and operating window of six upgraded SE-SMR processes for blue hydrogen production: 1) SE-SMR with an air fired calciner, 2) SE-SMR with a Pressure Swing Adsorption (PSA) unit, 3) SE-SMR thermally coupled with ChemicalLooping Combustion (CLC), 4) SE-SMR+PSA+CLC, 5) SE-SMR+PSA with an oxy-fired calciner, 6) SE$\mathrm{SMR}+\mathrm{PSA}$ with an indirect $\mathrm{H}_{2}$-fired calciner. Only natural gas was used as a feedstock in the previous process simulations. Within this paper, we investigate the economic performance of the proposed SE-SMR processes and calculate the impact of switching fuel supplies from natural gas to biomass. Hence, the following SE-SMR configurations are studied in this manuscript.

1) Case 1A: SE-SMR with the indirect air-natural gas combustion calciner

2) Case 1B: SE-SMR with the indirect air-biomass combustion calciner

3) Case 2A: SE-SMR with the indirect oxy-natural gas combustion calciner

4) Case 2B: SE-SMR with the indirect oxy-biomass combustion calciner

5) Case 3A: SE-SMR with the indirect chemical-looping combustion of natural gas calciner

6) Case 3B: SE-SMR with the indirect chemical-looping combustion of biomass calciner

Figure 1 illustrates the process for Case 1A and Case 1B. The natural gas feed to the reformer is compressed to 25 bar by the fuel compressor and preheated by the heat from the $\mathrm{CO}_{2}$ enriched gas from the calciner. Here, the feed water is supplied by a high-pressure pump goes through two heat exchangers heated by the hot syngas after the reformer and the flue gas from the air-fired combustor to produce the high-temperature steam. Then the mixture of natural gas, steam and $\mathrm{CaO}$ sorbent enters the fluidised bed reformer. The reformer in the SE-SMR process is operated as a joint carbonator and reformer, which can realise in-situ $\mathrm{CO}_{2}$ capture in the presence of $\mathrm{CaO}$ or other $\mathrm{CO}_{2}$ sorbents. The in-situ $\mathrm{CO}_{2}$ capture in the reformer shifts the reforming and water-gas shift reaction in the direction of increasing hydrogen production based on Le 
Chatelier's principle. The total SE-SMR reaction can be simplified as shown by Eq. (1). The reformer in the SE-SMR process is typically operated in the temperature range of 550 to $650{ }^{\circ} \mathrm{C}$ and elevated pressure ( $\sim 25$ bar) to reduce the energy penalty of $\mathrm{H}_{2}$ compression. The cooled syngas after the reformer is sent to the PSA unit to recover the $\mathrm{H}_{2}$ product and the off-gas which contains $\mathrm{CH}_{4}, \mathrm{CO}, \mathrm{CO}_{2}, \mathrm{H}_{2}$ and $\mathrm{H}_{2} \mathrm{O}$ is sent to the air-fired burner to reduce the additional fuel requirement. The calciner is operated at ambient pressure and indirectly heated by the combustion of natural gas and PSA off-gas with air. The air and fuel inlet of the burner are preheated by the remaining heat of the flue gas and $\mathrm{CO}_{2}$ product gas, respectively. The used sorbent is transported from the high-pressure reformer to the calciner via a depressurised lock hopper and the regenerated sorbent carried by the steam or $\mathrm{CO}_{2}$ is returned to the reformer through the pressurised lock hopper. Finally, the cooled $\mathrm{CO}_{2}$ from the calciner is compressed to 110 bar and cooled to room temperature in the form of a dense liquid suitable for transportation and storage. For the Case 1B, woody biomass together with the PSA off-gas is used as the fuel for the air-fired burner to provide the heat for the sorbent regeneration and steam generation. A gas cleaning unit, which consists of limestone flue gas desulphurisation (FGD) and selective catalytic reduction (SCR), is installed after the biomass combustor to remove the $\mathrm{SO}_{\mathrm{x}}$ and $\mathrm{NO}_{\mathrm{x}}$ in the flue gas.

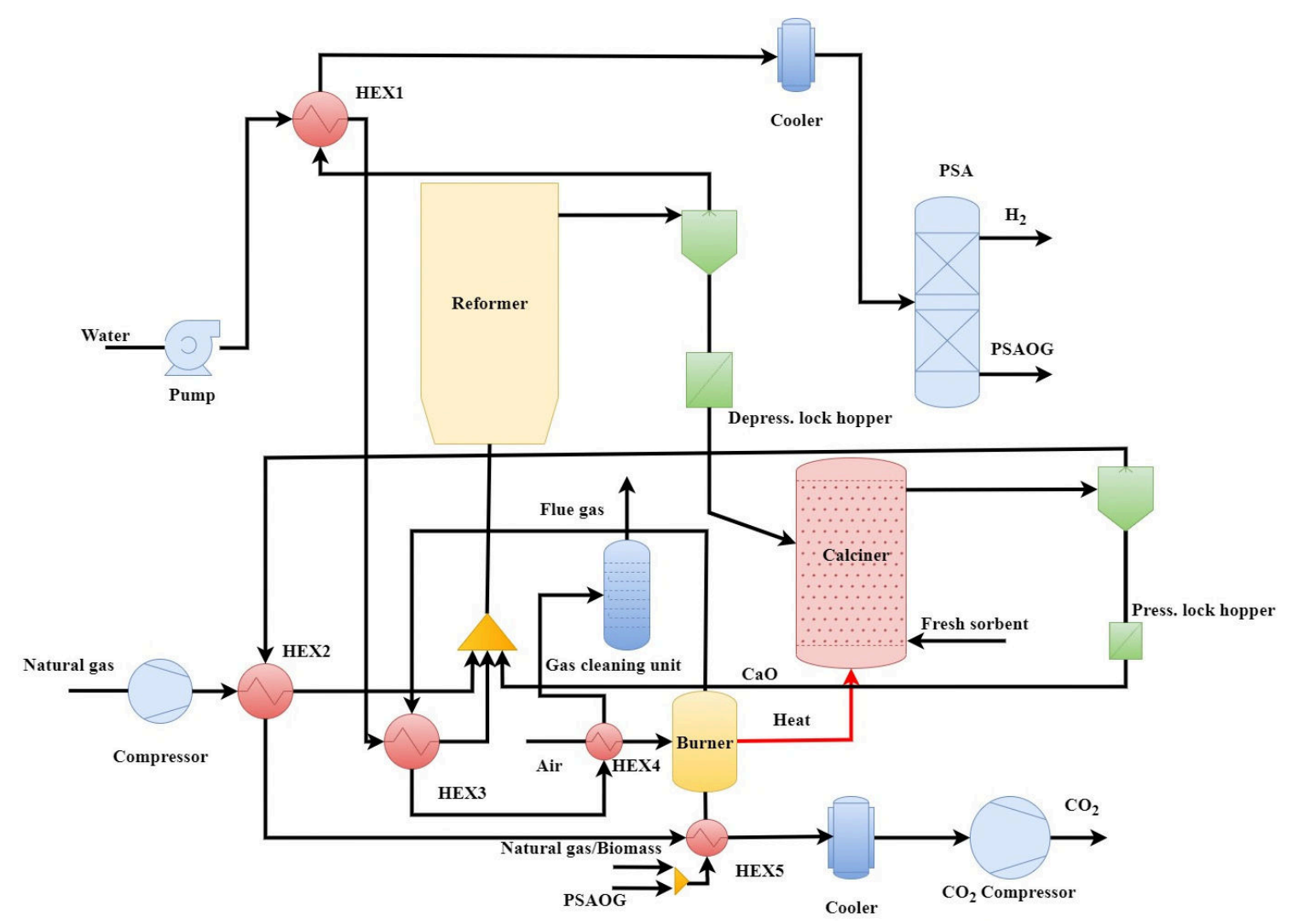

Figure 1 Simplified process flow diagram of Case 1A and B 
$\mathrm{CH}_{4}+2 \mathrm{H}_{2} \mathrm{O}+\mathrm{CaO} \leftrightarrow \mathrm{CaCO}_{3}+4 \mathrm{H}_{2}$

Equation (1)

To avoid the $\mathrm{CO}_{2}$ emissions from the indirectly air-fired calciner, an oxy-fuel burner has been coupled to the calciner to facilitate $\mathrm{CO}_{2}$ separation by providing the heat for sorbent regeneration and steam generation in Cases 2A and 2B as Figure 2 shown. Compared to the use of a direct oxy-fired calciner, the indirect oxy-fuel burner has the major advantage of providing an almost pure $\mathrm{CO}_{2}$ stream from the calciner, which minimises the energy for $\mathrm{CO}_{2}$ purification, and reduces sorbent make-up flow due to minimal impurities in the gas stream. To avoid superheated regions in the oxy-fuel burner, oxygen produced by the Air Separation Unit (ASU) is always mixed with the recirculated flue gas. Here, only a small amount of the $\mathrm{CO}_{2}$ enriched gas needs to be purified by the gas cleaning unit and then combined with the $\mathrm{CO}_{2}$ stream from the calciner for compression and storage.

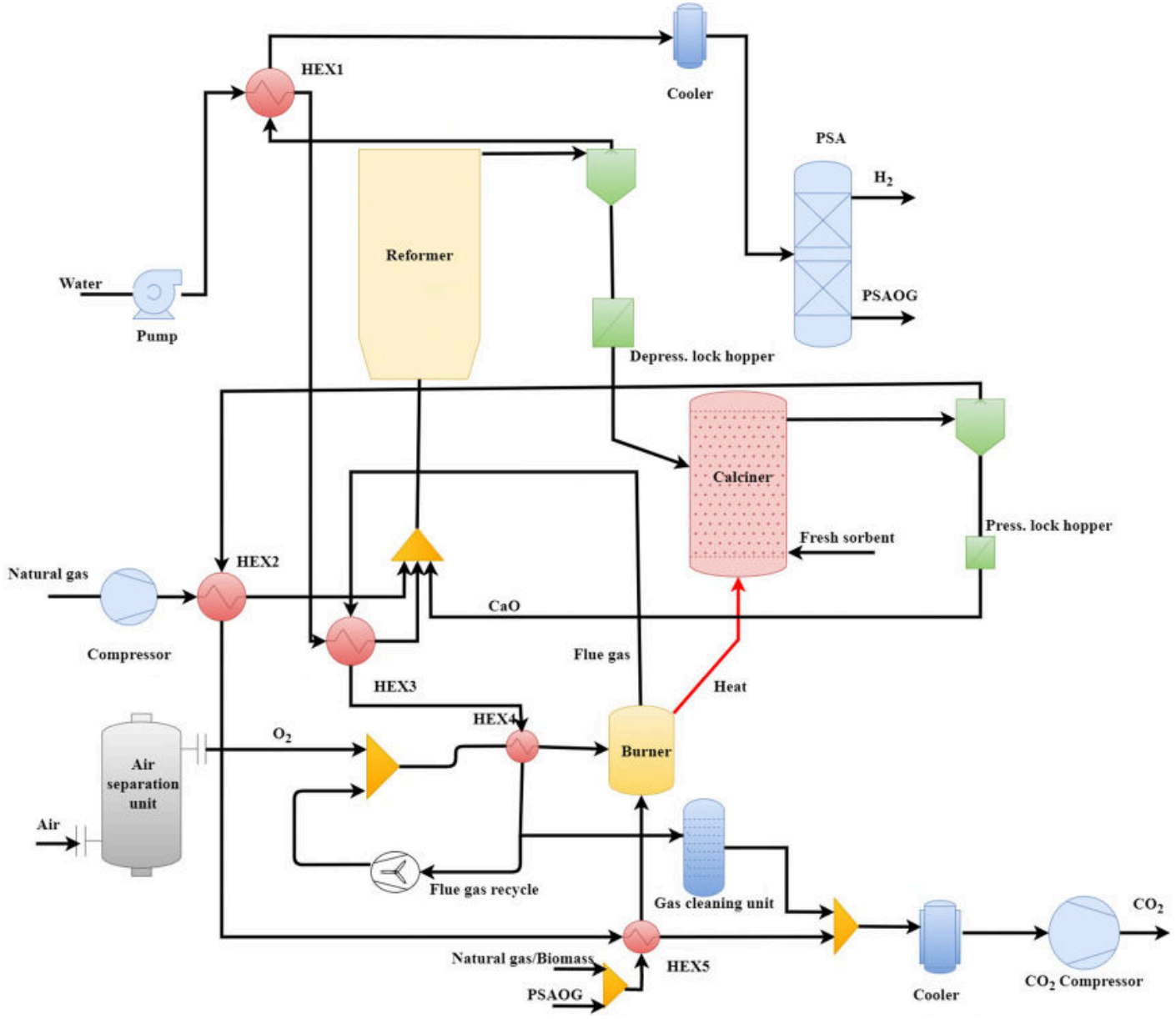

Figure 2 Simplified process flow diagram of Case 2A \& B

Another novel configuration for SE-SMR is thermally coupled chemical-looping combustion (CLC) for blue hydrogen production, which has been shown to be more efficient than SMR with CCS and SE-SMR with oxy-fuel combustion [14]. In the Case 3A and 3B (described in Figure 3), chemical-looping combustion of natural gas and biomass with PSA off-gas is employed to provide the necessary heat for SE- 
SMR, simultaneously realising inherent separation of $\mathrm{CO}_{2}$ without addition energy consumed. Iron oxide supported with $\mathrm{Al}_{2} \mathrm{O}_{3}(15 \mathrm{wt} \%)$ and $\mathrm{SiO}_{2}(15 \mathrm{wt} \%)$ was selected as the oxygen carrier of the CLC process due to its low-cost and its acceptable albeit moderate reactivity with fuels [18]. In the air reactor, the exothermic process in the oxidation of $\mathrm{Fe}_{3} \mathrm{O}_{4}$ by air (Eq. (2)) provides enough heat to the calciner via heat pipe exchangers. The heat from the depleted air is extracted for steam generation and preheating the air inlet. The oxidised oxygen carriers $\left(\mathrm{Fe}_{2} \mathrm{O}_{3}\right)$ are transported from the air reactor to react with natural gas (Case 3A) or biomass (Case 3B) and PSA off-gas in the fuel reactor, the resulting emissions consist of only $\mathrm{CO}_{2}$ and steam. The reactions in fuel reactor for Case 3A is described by Eq. (3) to (5). For Case 3B, chemical-looping combustion of biomass is a very complex process, it involves fuel devolatilisation (Eq. (6)) and char gasification (Eq. (7) and (8)) and their gaseous products react with the oxygen carriers as shown in Eq. (3) to (5). The $\mathrm{CO}_{2}$ enriched stream after the fuel reactor is combined with the $\mathrm{CO}_{2}$ stream from the calciner, and the heat is used to preheat the fuel feed. After that, the $\mathrm{CO}_{2}$ stream is purified and condensed for compression.

$$
\begin{array}{ll}
\mathrm{O}_{2}+4 \mathrm{Fe}_{3} \mathrm{O}_{4} \rightarrow 6 \mathrm{Fe}_{2} \mathrm{O}_{3} & \text { Equation (2) } \\
\mathrm{CH}_{4}+12 \mathrm{Fe}_{2} \mathrm{O}_{3} \rightarrow \mathrm{CO}_{2}+2 \mathrm{H}_{2} \mathrm{O}+8 \mathrm{Fe}_{3} \mathrm{O}_{4} & \text { Equation (3) } \\
\mathrm{H}_{2}+3 \mathrm{Fe}_{2} \mathrm{O}_{3} \rightarrow \mathrm{H}_{2} \mathrm{O}+2 \mathrm{Fe}_{3} \mathrm{O}_{4} & \text { Equation (4) } \\
\mathrm{CO}+3 \mathrm{Fe}_{2} \mathrm{O}_{3} \rightarrow \mathrm{CO}_{2}+2 \mathrm{Fe}_{3} \mathrm{O}_{4} & \text { Equation (5) } \\
\text { Biomass } \stackrel{\text { devolatilisation }}{\longrightarrow} \text { Volatiles }+\mathrm{C} & \text { Equation (6) } \\
\mathrm{C}+\mathrm{CO}_{2} \rightarrow 2 \mathrm{CO} & \text { Equation (7) } \\
\mathrm{C}+\mathrm{H}_{2} \mathrm{O} \rightarrow \mathrm{CO}+\mathrm{H}_{2} & \text { Equation (8) }
\end{array}
$$

\subsection{Process modelling}

The process modelling and mass-energy balance calculations used for the techno-economic analysis were performed by Aspen Plus V10. Table 1 shows the main parameters and assumptions used for the process simulation. Natural gas (see Table 2Table 1 for its composition) was used as a feedstock for the reformer for all cases. Only in Case 1B, 2B and 3B, the biomass is employed as the fuel to provide the heat of calcination for sorbent and steam generation. The proximate and ultimate analyses of the woody biomass used in this work are shown in Table 3, which is reported in [30]. The SRK (Soave-Redlich-Kwong) equation of state, which has shown good performance in simulations of hydrocarbon processing [31], was used for the process simulation of all cases. The mass flow rate of $\mathrm{H}_{2}$ product for all cases is set to 19.5 tonnes/h, equivalent to $650 \mathrm{MW}_{\text {th }}$ based on the lower heating value of $\mathrm{H}_{2}$. The SE-SMR $\mathrm{H}_{2}$ production plants are assumed to be located in Tees Valley, UK. A detailed Aspen Plus process flowsheet of each case with the values of mass flow rate, heat and work are shown in Supplementary materials. 
The SE-SMR process was simulated in Aspen Plus under steady-state equilibrium conditions. The RGibbs block, which calculates the chemical and phase equilibrium by minimising the Gibbs free energy of all components to achieve equilibrium, was used to model the reformer, calciner and combustor. To separate the solid phase from the gas phase, Sep model with $100 \%$ separation efficiency was used to simulate the cyclone of reformer and calciner. The calciner was operated at ambient pressure and the reformer was operated at 25 bar. It requires a depressurised lock hopper after the cyclone of reformer and a pressurised locker hopper after the cyclone of calciner to ensure the sorbent transported between the reformer and calciner under practical conditions. The pressures reported in this work are expressed as absolute pressure. According to experimental investigations $[9,10]$, it is reasonable to estimate that the average carbonation conversion of $\mathrm{CaO}$ sorbent under this SE-SMR conditions can achieve $50 \%$, which can be maintained by ensuring an effective make-up flow of the sorbent/composite particles.

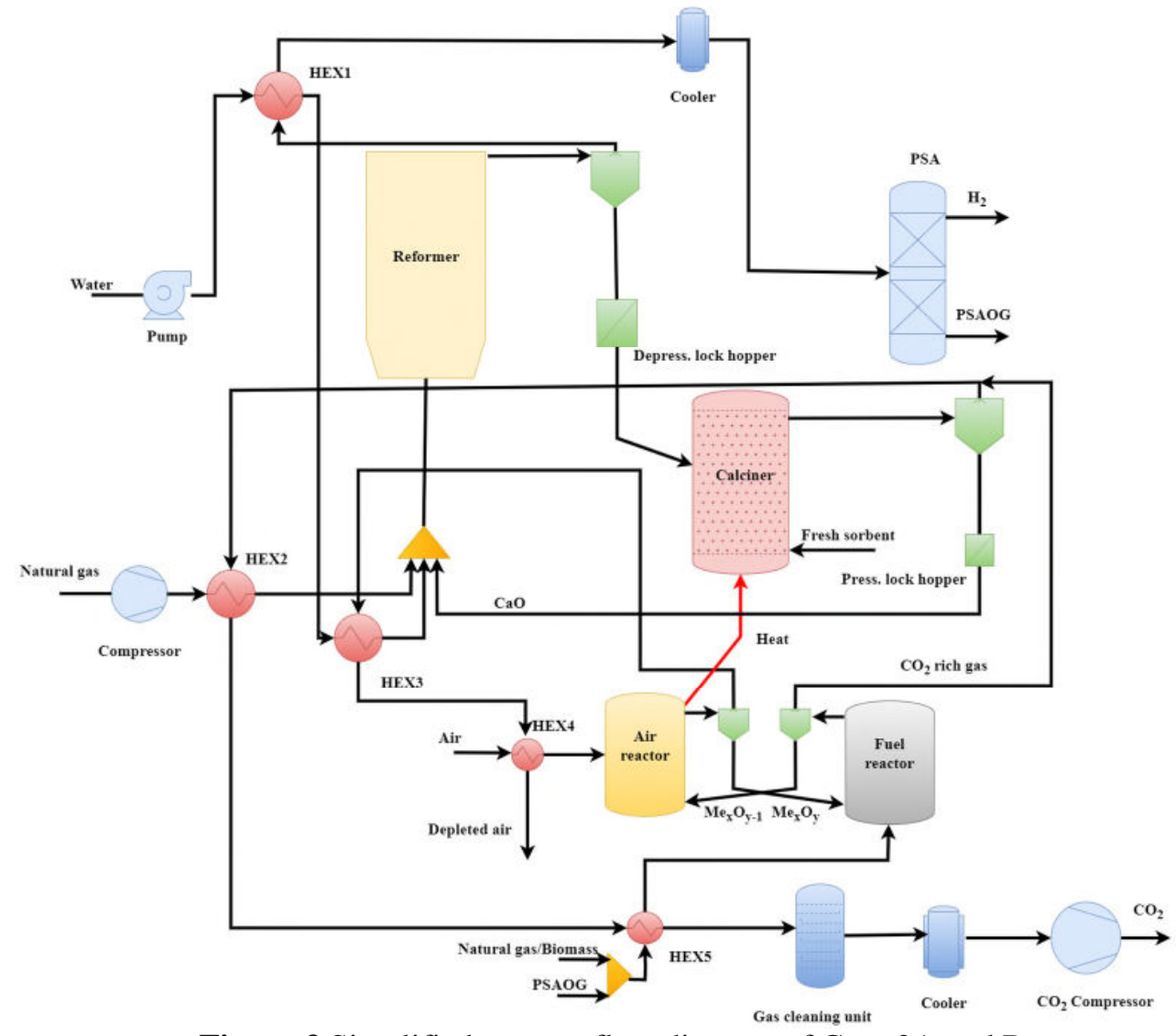

Figure 3 Simplified process flow diagram of Case 3A and B

The natural gas feed to the reformer is adjusted to ensure the mass flow rate of $\mathrm{H}_{2}$ product is 19.5 tonnes/h for all cases with the $\mathrm{S} / \mathrm{C}=5$. The pure hydrogen is recovered from the water-condensed $\mathrm{H}_{2}$ enriched gas using a pressure swing adsorption (PSA) unit with 95\% recovery efficiency [32], which was stimulated by the Sep model in Aspen Plus. The inlet pressure of condensed $\mathrm{H}_{2}$ enriched gas to the PSA unit is maintained 
over 25 bar, which is the common operating pressure for PSA. Then, the pressurised $\mathrm{H}_{2}$ product at room temperature can be stored or distributed. The off-gas from the PSA unit, which contains $\mathrm{H}_{2}, \mathrm{CO}$, and $\mathrm{CH}_{4}$, can be burned with natural gas or biomass to help meet the calciner heat duty.

The MHeatX model was selected to simulate the heat exchangers and heat recovery steam generator (HRSG) for all the cases. The goal of heat exchanger networks design is to obtain the maximum heat recovery with the minimum number of heat exchangers. The steam generator was simulated with multiple zones to detect and avoid temperature crossover during the phase transition.

The process of biomass combustion was simulated by the modified models shown elsewhere [33]. For the Case 2B, a mixture of $\mathrm{O}_{2}$ and recirculated flue gas were used as an oxidant for the inlet of RGibbs block. For the Case 3B, $\mathrm{Fe}_{2} \mathrm{O}_{3}$ was used as an oxidant for the inlet of RGibbs block. Finally, the SSplit model was used as a cyclone to separate the combustion gases from ash, and the heat of the combustion gases could be further extracted by the heat exchangers. For the Case 2A and 2B, the ASU was not modelled, but the specific energy of oxygen separation was set to $160 \mathrm{kWh} /$ tonne $\mathrm{O}_{2}$ for the techno-economic analysis [34]. The mass flow rate of recirculated flue gas was adjusted to maintain the $\mathrm{O}_{2}$ volume concentration at $30 \%$ in the oxy-fuel combustor to control flame temperature [35].

In the Case $3 \mathrm{~A}$ and $3 \mathrm{~B}$, an RGibbs block was selected to model both the air reactor (AR) and fuel reactor (FR). A heat stream was used to carry the heat from oxidation of $\mathrm{Fe}_{3} \mathrm{O}_{4}$ in the air reactor (AR) to meet the heat duty of calciner. It was assumed a $10 \%$ heat loss during the heat transfer from the AR to the calciner. The outlet temperature of the AR varied as the change in heat duty of calciner, but it was always maintained higher than the calciner operating temperature $\left(900^{\circ} \mathrm{C}\right)$. The FR was set to an adiabatic reactor and its temperate was decided by the inlet conditions of fuel and oxygen carriers. The mass flow of oxygen carriers to the FR was determined by all hydrogen was completely combusted in the outlet flue gas of the FR. The heat of depleted air from the AR and $\mathrm{CO}_{2}$ enriched gas from the FR were used to generate steam and preheat the air and fuel. Both the AR and FR were operated at ambient pressure. The gas cleaning unit of all the biomass combustion cases is simulated by a separator, which is assumed that the $\mathrm{SO}_{\mathrm{x}}$ and $\mathrm{NO}_{\mathrm{x}}$ are completely removed from flue gas. 
Table 1 Main parameters and assumptions for process simulation in Aspen plus

\begin{tabular}{|c|c|c|c|}
\hline Parameters & Value & Unit & Reference \\
\hline Reformer pressure & 25 & bar & [18] \\
\hline Reformer temperature & 600 & ${ }^{\circ} \mathrm{C}$ & [18] \\
\hline Steam to carbon $(\mathrm{S} / \mathrm{C})$ ratio & 5 & - & [18] \\
\hline Calciner temperature & 900 & ${ }^{\circ} \mathrm{C}$ & [14] \\
\hline Isentropic efficiency of natural gas and $\mathrm{CO}_{2}$ compressor & 83 & $\%$ & [14] \\
\hline Water pump efficiency & 83 & $\%$ & [14] \\
\hline Excess oxygen & 10 & $\%$ & [36] \\
\hline Calciner heat loss & 10 & $\%$ & [18] \\
\hline Calcination efficiency & 100 & $\%$ & [14] \\
\hline Mechanical efficiency of pump and compressors & 98 & $\%$ & [14] \\
\hline Fuel feed temperature & 9 & ${ }^{\circ} \mathrm{C}$ & / \\
\hline Fuel feed pressure & 1 & bar & / \\
\hline Feed water inlet temperature & 10 & ${ }^{\circ} \mathrm{C}$ & / \\
\hline Feed water inlet pressure & 1 & bar & / \\
\hline Air/oxygen temperature & 20 & ${ }^{\circ} \mathrm{C}$ & l \\
\hline Air/oxygen pressure & 1 & bar & / \\
\hline Stack temperature of flue gas & 120 & ${ }^{\circ} \mathrm{C}$ & I \\
\hline Lower heating value of $\mathrm{H}_{2}$ & 120 & $\mathrm{MJ} / \mathrm{kg}$ & [37] \\
\hline Lower heating value of wood pellets & 17 & $\mathrm{MJ} / \mathrm{kg}$ & [38] \\
\hline Lower heating value of natural gas & 46.02 & $\mathrm{MJ} / \mathrm{kg}$ & [39] \\
\hline
\end{tabular}


Table 2 Composition of natural gas [39]

\begin{tabular}{cc}
\hline Composition of natural gas & Unit (mol. \%) \\
\hline $\mathrm{CH}_{4}$ & 92.03 \\
$\mathrm{C}_{2} \mathrm{H}_{6}$ & 5.75 \\
$\mathrm{C}_{3} \mathrm{H}_{8}$ & 1.31 \\
$\mathrm{C}_{4+}$ & 0.45 \\
$\mathrm{~N}_{2}$ & 0.46
\end{tabular}

Table 3 Proximate and ultimate analyses of the woody biomass [30]

\begin{tabular}{cc}
\hline Proximate analysis (wt $\%$, as received) \\
\hline Moisture & 4.97 \\
Volatile matter & 78.30 \\
Fixed carbon & 14.93 \\
Ash content & 1.79 \\
\hline \multicolumn{2}{c}{ Ultimate analysis (wt\%, as received) } \\
\hline C & 47.91 \\
H & 6.70 \\
N & 0.12 \\
S & 0.04 \\
O (by difference) & 45.27 \\
\hline
\end{tabular}

The key performance indicators to evaluate the thermodynamic performance of different SE-SMR processes are cold gas efficiency, net efficiency and $\mathrm{CO}_{2}$ capture efficiency. Because the PSA unit has been installed and the off-gas of PSA unit (PSAOG) has been utilised in all cases, the $\mathrm{H}_{2}$ purity and total natural gas conversion for all the cases are close to $100 \%$.

The cold gas efficiency $\left(\eta_{C G}\right)$ is calculated by Eq. (9).

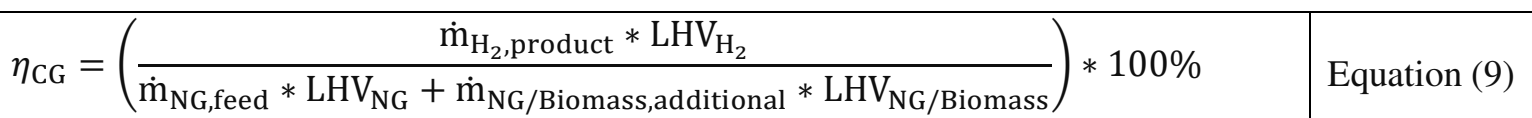

Where $\dot{\mathrm{m}}_{\mathrm{H}_{2} \text {,product }}, \dot{\mathrm{m}}_{\mathrm{NG} \text {,feed }}$ and $\dot{\mathrm{m}}_{\mathrm{NG} / \text { Biomass,additional }}$ are the mass flow rate of the hydrogen product, natural gas feed and additional natural gas or biomass required to meet the heat utility of the calciner and steam boiler, respectively, $\mathrm{LHV}_{\mathrm{H}_{2}}$ and $\mathrm{LHV} \mathrm{NG}_{\mathrm{N} / \text { Biomass }}$ are the lower heating value of hydrogen and natural gas or biomass, respectively.

The net efficiency $\left(\eta_{\text {net }}\right)$ is calculated as shown in Eq. (10), where the electric utility $\left(\mathrm{P}_{\mathrm{e}}\right)$ requirement is also added to the cold gas efficiency equation. A thermal to electrical conversion efficiency $\left(\eta_{\text {elect }}\right)$ of $50 \%$ is utilised in this work. 


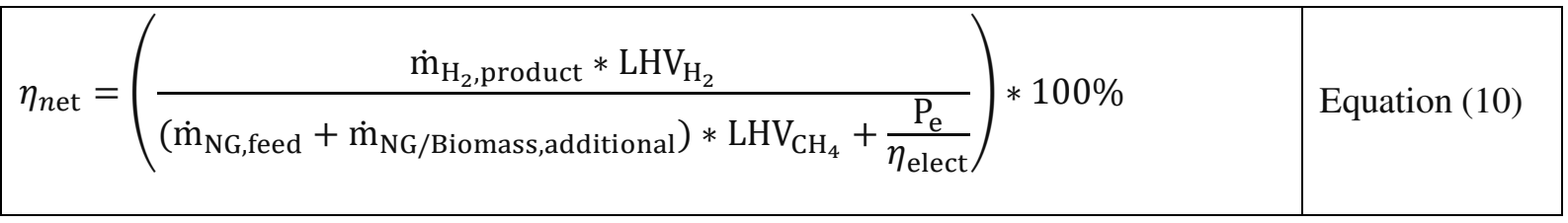
The overall $\mathrm{CO}_{2}$ capture efficiency is calculated using Eq. (11). In this work, only the $\mathrm{CO}_{2}$ emissions of SE-SMR plants are considered and biomass is considered to be a carbon-neutral fuel.

\begin{tabular}{|l|l|}
\hline $\mathrm{CO}_{2}$ capture efficiency $=\left(\frac{\mathrm{n}_{\mathrm{CO}_{2}, \text { captured }}}{\mathrm{n}_{\mathrm{NG}, \text { feed }}+\mathrm{n}_{\mathrm{NG} / \text { Biomass,additional }}}\right) * 100 \%$ & Equation (11) \\
\hline
\end{tabular}

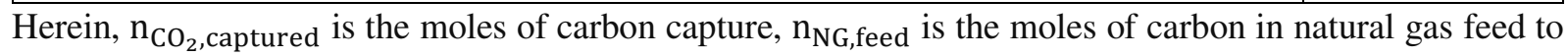
the reformer, and $\mathrm{n}_{\mathrm{NG}}$ /Biomass,additional is the moles of carbon in natural gas or biomass feed to the combustor or FR.

\subsection{Economic evaluation}

Detailed cost estimation of the above different SE-SMR configurations is conducted to compare their economic performance. A chemical plant cost estimation methodology developed by Sinnott et al. [40] for calculating the capital and operating costs is employed. The capital cost consists of direct capital costs of the major equipment, such as the reformer, calciner, heat recovery steam generator (HRSG), pressure swing adsorption (PSA) unit, chemical-looping combustion (CLC) unit and $\mathrm{CO}_{2}$ compressor, and indirect capital costs. The direct capital costs of the major equipment are based on the estimation of corresponding units from the literature and corrected to a consistent baseline year (2019) by employing chemical engineering plant cost index factors and equipment scaling exponents as Eq. (12) shown [40].

$$
\begin{array}{|l|l|}
\hline \mathrm{C}_{\mathrm{A}}=\left(\frac{\mathrm{CI}_{\mathrm{A}}}{\mathrm{CI}_{\mathrm{B}}}\right) * \mathrm{C}_{\mathrm{B}} *\left(\frac{\mathrm{S}_{\mathrm{A}}}{\mathrm{S}_{\mathrm{B}}}\right)^{\mathrm{X}} & \text { Equation (12) } \\
\hline
\end{array}
$$

Where $C_{A}$ is the new scaled equipment cost, $C_{B}$ is the base equipment cost, $\mathrm{CI}_{A}$ and $\mathrm{CI}_{\mathrm{B}}$ are the annual chemical engineering plant cost index factor in the year $\mathrm{A}$ and $\mathrm{B}$ respectively, $\mathrm{S}_{\mathrm{A}}$ is the new equipment's capacity, $S_{B}$ is the base equipment's capacity, and $\mathrm{x}$ is the scaling exponent for the equipment, which is taken as 0.6 in this work, as known as the six-tenths rule.

The operating cost is made up of the fixed costs, variable costs and fuel costs. The price of the raw materials and fuel is obtained from the quotations of potential suppliers and literature. Parameters and assumptions for the capital and operating costs are described in Table 4. The costs of shipping and distributing $\mathrm{H}_{2}$ product are not considered in this work. It is assumed that the proposed cases are the central hydrogen production plants and that a distribution network is available. 
The key economic performance indicators used in this analysis are the levelised cost of hydrogen (LCOH), the cost of $\mathrm{CO}_{2}$ avoided (CCA) and removal (CCR). These costs are calculated by the following equations $[29,41]$ :

\begin{tabular}{|l|l|}
\hline $\mathrm{LCOH}=\frac{(\mathrm{TOC} * \mathrm{FCF}+\mathrm{FOM})}{(\mathrm{CF} * 8760)}+(\mathrm{FC} * \mathrm{HR})+\mathrm{VOM}$ & Equation (13) \\
\hline $\mathrm{CCA}=\frac{\mathrm{LCOH}_{\mathrm{SE}-\mathrm{SMR}}-\mathrm{LCOH}_{\mathrm{Non} \mathrm{CCS}}}{\mathrm{CO}_{2} \text { Emissions }_{\mathrm{Non} \mathrm{CCS}}-\mathrm{CO}_{2} \text { Emissions }_{\mathrm{SE}-\mathrm{SMR}}}$ & Equation (14) \\
\hline $\mathrm{CCR}=\frac{\mathrm{LCOH}_{\mathrm{SE}-\mathrm{SMR}}-\mathrm{LCOH}_{\mathrm{Non} \mathrm{CCS}}}{\mathrm{CO}_{2} \text { Removed }_{\mathrm{SE}-\mathrm{SMR}}}$ & Equation (15) \\
\hline
\end{tabular}

Where TOC is the total overnight capital cost, FOM is the fixed operating and maintenance costs, VOM is the variable operating and maintenance costs, FC is the fuel costs, $\mathrm{CF}$ is the capacity factor, HR is the net heat rate of the plant, and FCF is the fixed charge factor as defined in Eq. (16) [40].

$\mathrm{FCF}=\frac{\mathrm{r}(1+\mathrm{r})^{\mathrm{t}}}{(1+\mathrm{r})^{\mathrm{t}}-1}$ Equation (16)

Herein, $t$ is the economic lifetime of the plant relative to its base year, and $r$ is the discount rate. In this study, a plant lifetime of 30 years and a discount rate of $12 \%$ obtained from the report of discount rates for low-carbon and renewable generation technologies in the UK [42] are used.

The value of LCOH with and without a carbon price (£16/tonne [43]) of an SMR plant ( $\mathrm{LCOH}_{\text {Non CCS }}$ ) is $£ 2.17$ and $£ 1.33 / \mathrm{kg} \mathrm{H}_{2}$ [44], and the $\mathrm{CO}_{2}$ emissions of SMR plant without carbon capture $\left(\mathrm{CO}_{2}\right.$ Emissions ${ }_{\text {Non }}$ CCS) is assumed to be $10 \mathrm{~kg} / \mathrm{kg} \mathrm{H} \mathrm{H}_{2}$ [26].

\subsection{Sensitivity analysis}

It is necessary to find the key parameters and consider their uncertainties that can affect the economic performance of the proposed SE-SMR for blue or carbon-negative hydrogen production. Thus, a sensitivity analysis is carried out in this work to evaluate the impact of the change in six parameters, which are the total direct capital cost (TDCC), discount rate, fuel costs, $\mathrm{CO}_{2}$ storage cost, operating capacity factor and net efficiency, on the $\mathrm{LCOH}$.

To investigate the profitability of the proposed cases, net present value (NPV) has been calculated according to Eq. (17) [40], and different $\mathrm{H}_{2}$ selling prices have been applied to evaluate the profitability performance of proposed cases. 
\begin{tabular}{|l|l|}
\hline $\mathrm{NPV}=\sum_{\mathrm{n}=1}^{\mathrm{n}=\mathrm{t}} \frac{\mathrm{NCF}_{\mathrm{n}}}{(1+\mathrm{r})^{\mathrm{n}}}$ & Equation (17) \\
\hline
\end{tabular}

Where $\mathrm{NCF}_{\mathrm{n}}$ is the net cash flow in year $n$.

Table 4 Parameters and assumptions for economic analysis

\begin{tabular}{|c|c|c|}
\hline Parameter & Value & Reference \\
\hline Specific cost of reformer $\left(£ / \mathrm{kW}_{\text {th }}\right)$ & 55.3 & [26] \\
\hline Specific cost of calciner $\left(\mathfrak{f} / \mathrm{kW}_{\mathrm{th}}\right)$ & 171.5 & [45] \\
\hline Specific cost of CLC unit $\left(£ / \mathrm{kW}_{\text {th }}\right)$ & 178.8 & [46] \\
\hline Specific cost of heat recovery steam generator $\left(£ / \mathrm{kW}_{\text {th }}\right)$ & 112.8 & [47] \\
\hline Specific cost of Sulphur removal unit $\left(£ / \mathrm{kW}_{\text {th }}\right)$ & 38.3 & [41] \\
\hline Cost of PSA unit (£m) & 90.3 & [26] \\
\hline Cost of ASU (£m) & 32.0 & [26] \\
\hline Cost of $\mathrm{CO}_{2}$ compressor $(£ \mathrm{~m})$ & 37.7 & [48] \\
\hline Cost of $\mathrm{CO}_{2}$ storage ( $£ /$ tonne) & 19 & [49] \\
\hline Heat pipe (£/pipe) & 179.3 & {$[24]$} \\
\hline Natural gas price ( $(/ \mathrm{MWh})$ & 15.4 & [50] \\
\hline Biomass price (£/MWh) & 19.0 & [50] \\
\hline Electricity price $(\mathfrak{f} / \mathrm{kWh})$ & 0.16 & [51] \\
\hline Process water (Including waste water treatment, $£ / \mathrm{m}^{3}$ ) & 3.1 & [52] \\
\hline Ni catalyst ( $£ / k g$, life span: 5 years) & 24.5 & [53] \\
\hline $\begin{array}{l}\mathrm{Fe}_{2} \mathrm{O}_{3} \text { oxygen carriers (Including disposal cost, } £ / \mathrm{kg} \text {, life } \\
\text { span: } 3000 \mathrm{~h} \text { ) }\end{array}$ & 1.5 & {$[26]$} \\
\hline Limestone (£/tonne, life span: $500 \mathrm{~h}$ ) & 85 & [54] \\
\hline Solid inventory of $\mathrm{CaCO}_{3}\left(\mathrm{~kg} / \mathrm{m}^{2}\right)$ & 1000 & {$[55]$} \\
\hline Solid inventory of the fuel reactor $\left(\mathrm{kg} / \mathrm{MW}_{\text {th }}\right)$ & 500 & [56] \\
\hline Solid inventory of the air reactor $\left(\mathrm{kg} / \mathrm{MW}_{\mathrm{th}}\right)$ & 250 & {$[56]$} \\
\hline Industrial land value (Tees Valley, £m/hectare) & 0.32 & [57] \\
\hline Chemical Engineering Plant Cost Index (CEPCI) 2019 & 607.5 & [58] \\
\hline Plant staff & \multicolumn{2}{|c|}{35} \\
\hline Burdened labour cost (Including the overheads, £/man-hr) & \multicolumn{2}{|c|}{25} \\
\hline Plant life (year) & \multicolumn{2}{|c|}{30} \\
\hline Capacity factor & \multicolumn{2}{|c|}{0.95} \\
\hline
\end{tabular}




$\begin{array}{ll}\text { Design and engineering } & \begin{array}{l}20 \% \text { of total direct capital costs of } \\ \text { equipment } \\ \text { Contractor's fee }\end{array} \\ & \begin{array}{l}5 \% \text { of total direct capital costs of } \\ \text { equipment }\end{array} \\ & 5 \% \text { of total direct capital costs of } \\ \text { Contingency allowance } & 10 \% \text { of total capital costs } \\ \text { Maintenance } & 10 \% \text { of maintenance cost } \\ \text { Miscellaneous materials } & 1 \% \text { of total capital costs per year } \\ \text { Insurance } & 1 \% \text { of total capital costs per year } \\ \text { Local taxes } & 10 \% \text { of the operating labour costs } \\ \text { Supervision } & 20 \% \text { of the operating labour costs } \\ \text { Laboratory costs } & 60 \% \text { of the operating labour costs } \\ \text { Plant overheads } & \end{array}$

\section{Results and discussion}

\subsection{Technical performance analysis}

The detailed technical performance of six different SE-SMR plants is shown in Table 5. Case 2A has the highest cold gas efficiency (82.59\%), but its net efficiency is $3.24 \%$ and $0.9 \%$ points respectively lower than those of Case 1A (76.96\%) and 3A (74.10\%) due to the high electricity consumption of the ASU. Case $1 \mathrm{~A}$ has the highest net efficiency (76.96\%), but the lowest $\mathrm{CO}_{2}$ capture efficiency $(60.08 \%)$, because only the $\mathrm{CO}_{2}$ from the reformer has been captured by $\mathrm{CaO}$ sorbent, and the $\mathrm{CO}_{2}$ from the indirect-air natural gas combustion calciner is released directly to the atmosphere. When biomass is used as the fuel to meet the heat duty of calciner and steam generation (Case 1B) the system can achieve the highest net efficiency (70.52\%) with overall $\mathrm{CO}_{2}$ capture efficiency of $86.08 \%$. While Case $2 \mathrm{~B}$ and $3 \mathrm{~B}$ can realise nearly $100 \%$ overall $\mathrm{CO}_{2}$ capture efficiency with a $4.19 \%$ and $1.2 \%$ drop in net efficiency compared that of the Case $1 \mathrm{~A}$. In addition, Case $2 \mathrm{~B}$ and $3 \mathrm{~B}$ can achieve negative $\mathrm{CO}_{2}$ emissions for hydrogen production, which can remove 5.4 and $5.5 \mathrm{~kg} \mathrm{CO}_{2}$ respectively from the atmosphere per $\mathrm{kg}$ of hydrogen produced. It is worth noting that the replacement of natural gas by biomass in the indirectly heated calciner significantly decreases both the cold gas and net efficiencies by $\sim 5-7 \%$ points for these cases because of heat loss in biomass combustion. To improve its efficiency, it is required to further improve the optimisation of their heat network integration to achieve maximum heat recovery. Compared with the SMR with amine-based scrubbing system, the cold gas efficiency of proposed SE-SMR configurations is significantly higher than that of SMR with amine-based scrubbing system (69\%) [25]. 
The natural gas conversion in the reformer and $\mathrm{H}_{2}$ purity (dry basis, before PSA) for all the proposed SESMR configuration is $86 \%$ and $96 \%$, respectively, which is much greater than those of conventional SMR process. Hence, SE-SMR process without PSA is optimal for some low-purity $\mathrm{H}_{2}$ required applications. With the use of PSA, the $\mathrm{H}_{2}$ purity can be nearly $100 \%$ and the PSA off-gas can be used to provide the heat to calciner, which makes the overall natural gas conversion approach to $100 \%$.

The $\mathrm{NO}_{\mathrm{x}}$ and $\mathrm{SO}_{\mathrm{x}}$ emissions increase significantly when natural gas is replaced by biomass to meet the heat duty of calciner and steam generation. But the $\mathrm{NO}_{\mathrm{x}}$ emissions of Case $1 \mathrm{~B}, 2 \mathrm{~B}$ and $3 \mathrm{~B}$ are well below the EU directive on industrial $\mathrm{NO}_{\mathrm{x}}$ emissions of biomass combustion $\left(250 \mathrm{mg} / \mathrm{Nm}^{3}\right)$. For $\mathrm{SO}_{\mathrm{x}}$ emissions, only in Case $3 \mathrm{~B}$ is the value $\left(308 \mathrm{mg} / \mathrm{Nm}^{3}\right.$ ) over the limitation for industrial $\mathrm{SO}_{\mathrm{x}}$ emissions for biomass combustion $\left(250 \mathrm{mg} / \mathrm{Nm}^{3}\right)$. It would be necessary to add a gas cleaning unit to further purify the $\mathrm{CO}_{2}$ stream before the $\mathrm{CO}_{2}$ compression in Case $2 \mathrm{~B}$ and $3 \mathrm{~B}$, to avoid the risk of corrosion throughout transport pipelines and plant components.

The current TRL of SE-SMR for hydrogen production is at 4, and a series of studies have been done to develop the sorbents, catalysts, reactor design, system integration and optimisation. In this work, we proposed six new SE-SMR configurations for low-carbon hydrogen production. The TRL of Case 1A, 1B, $2 \mathrm{~A}$ and $2 \mathrm{~B}$ is estimated at 4 , and 3 for Case $3 \mathrm{~A}$ and $3 \mathrm{~B}$. The experience of operating the pilot-scale indirectly heated calciner, calcium looping, and chemical-looping combustion facilities can be used to accelerate the development of proposed SE-SMR configurations in this work. There are some key challenges in scale-up for the proposed SE-SMR processes. It is necessary to investigate the performance of the indirectly heated calciner. Looking at, in particular, the heat transfer and heat loss through the heat pipes between the combustor/ air reactor to the calciner, and the effects of heat pipes on the fluidisation and cycling of the solids.

Table 5 Technical performance indicators of SE-SMR $\mathrm{H}_{2}$ production plants

\begin{tabular}{clllllll}
\hline Cases & Units & Case 1A & Case 1B & Case 2A & Case 2B & Case 3A & Case 3B \\
\hline Natural gas & tonne/h & 62.8 & 48.4 & 61.6 & 48.4 & 64.3 & 48.4 \\
Biomass & tonne/h & 0.0 & 57.6 & 0.0 & 55.0 & 0.0 & 56.5 \\
Boiler feed water & tonne/h & 273.0 & 273.0 & 281.9 & 273.0 & 272.8 & 300.7 \\
Fuel compressor & $\mathrm{MW}_{\text {th }}$ & 10.3 & 10.3 & 10.3 & 10.3 & 10.3 & 10.3 \\
Water pump & $\mathrm{MW}_{\text {th }}$ & 0.2 & 0.2 & 0.2 & 0.2 & 0.2 & 0.2 \\
$\mathrm{CO}_{2}$ compressor & $\mathrm{MW}_{\text {th }}$ & 10.8 & 10.8 & 16.0 & 20.7 & 17.2 & 20.9 \\
Air separation unit & $\mathrm{MW}_{\text {th }}$ & 0.0 & 0.0 & 20.7 & 25.1 & 0.0 & 0.0 \\
Calciner & $\mathrm{MW}_{\text {th }}$ & 160.9 & 160.9 & 166.1 & 160.8 & 160.5 & 160.5
\end{tabular}




\begin{tabular}{|c|c|c|c|c|c|c|c|}
\hline $\begin{array}{c}\text { Combustor/CLC } \\
\text { unit }\end{array}$ & $\mathrm{MW}_{\text {th }}$ & 274.5 & 311.4 & 269.6 & 299.5 & 291.00 & 374.6 \\
\hline $\mathrm{H}_{2}$ product flowrate & tonne/h & 19.5 & 19.5 & 19.5 & 19.5 & 19.5 & 19.5 \\
\hline $\mathrm{H}_{2}$ product $(\mathrm{LHV})$ & $\mathrm{MW}_{\text {th }}$ & 650 & 650 & 650 & 650 & 650 & 650 \\
\hline Cold gas efficiency & $\%$ & 81.0 & 73.9 & 82.6 & 74.9 & 79.1 & 74.4 \\
\hline Net efficiency & $\%$ & 77.0 & 70.5 & 73.7 & 66.3 & 74.1 & 69.4 \\
\hline $\begin{array}{l}\mathrm{CO}_{2} \text { capture } \\
\text { efficiency }\end{array}$ & $\%$ & 60.1 & 86.1 & 100.0 & 100.0 & 100.0 & 99.7 \\
\hline $\mathrm{CO}_{2}$ captured & $\begin{array}{l}(\mathrm{kg} / \mathrm{kg} \\
\left.\mathrm{H}_{2}\right)\end{array}$ & 5.88 & 5.88 & 8.69 & 11.29 & 9.08 & 11.40 \\
\hline $\mathrm{CO}_{2}$ emissions & $\begin{array}{l}(\mathrm{g} / \mathrm{kg} \\
\left.\mathrm{H}_{2}\right)\end{array}$ & 2980 & 0.49 & 0.34 & -5410 & 0.43 & -5520 \\
\hline $\mathrm{NO}_{\mathrm{x}}$ emissions & $\mathrm{mg} / \mathrm{Nm}^{3}$ & 2.21 & 59.67 & 0.01 & 3.56 & 0.02 & 0.01 \\
\hline $\mathrm{SO}_{\mathrm{x}}$ emissions & $\mathrm{mg} / \mathrm{Nm}^{3}$ & 0.00 & 58.21 & 0.00 & 93.87 & 0.00 & 308.00 \\
\hline
\end{tabular}

\subsection{Economic analysis}

\subsubsection{Economic performance}

Table 6 presents the detailed results of economic analysis of the different SE-SMR processes. The integration of SE-SMR with oxy-biomass combustion calciner (Case 2B) has the highest total capital and operating costs ( $£ 293 \mathrm{~m}$ and $£ 329 \mathrm{~m}$, respectively) compared to that of the other cases. The replacement of oxy-fuel combustion unit by the CLC unit in Case 3B decreased the total capital and operating costs relative to Case $2 \mathrm{~B}$ by $2.76 \%$ points and $9.36 \%$ points respectively. While, the total capital and operating costs of Case $3 \mathrm{~A}$ has increased by $6.21 \%$ points and $3.04 \%$ points compared to the Case $3 \mathrm{~A}$, which is due to the increase in the capacity of $\mathrm{CO}_{2}$ compression unit in case $3 \mathrm{~A}$. Case $1 \mathrm{~A}$ has the lowest total capital and operating costs ( $£ 189 \mathrm{~m}$ and $£ 238 \mathrm{~m}$ ) but with the lowest $\mathrm{CO}_{2}$ capture efficiency $(60.08 \%)$ ). The total capital and operating costs of Case $1 \mathrm{~A}$ are increased by $2.47 \%$ points and $6.48 \%$ points when biomass replaces the natural gas as the feed of the indirect calciner (Case 1B), but the $\mathrm{CO}_{2}$ capture efficiency is increased by $30.2 \%$ points.

Table 6 Main results of economic analysis of SE-SMR hydrogen plants

\begin{tabular}{cccccccc}
\hline Cases & Units & Case 1A & Case 1B & Case 2A & Case 2B & Case 3A & Case 3B \\
\hline \multirow{7}{*}{ Deformer } & $£ \mathrm{~m}$ & 34.2 & 34.2 & 34.2 & 34.2 & 34.2 & 34.2 \\
Calciner \&combustor & $£ \mathrm{~m}$ & 27.6 & 27.6 & 28.5 & 27.6 & 27.5 & 27.5
\end{tabular}




\begin{tabular}{|c|c|c|c|c|c|c|}
\hline PSA & $£ \mathrm{~m}$ & 39.5 & 39.5 & 39.5 & 39.5 & 39.5 \\
\hline CLC unit & $£ \mathrm{~m}$ & 0.0 & 0.0 & 0.0 & 0.0 & 36.4 \\
\hline ASU & $£ \mathrm{~m}$ & 0.0 & 0.0 & 37.9 & 63.4 & 0.0 \\
\hline $\mathrm{CO}_{2}$ compressor & $£ \mathrm{~m}$ & 13.5 & 13.5 & 20.2 & 26.1 & 26.1 \\
\hline Gas cleaning unit & $£ \mathrm{~m}$ & 0.0 & 3.3 & 0.0 & 3.3 & 0.0 \\
\hline $\begin{array}{c}\text { HRSG \& Heat } \\
\text { exchangers }\end{array}$ & $£ \mathrm{~m}$ & 27.9 & 27.9 & 27.9 & 27.9 & 29.8 \\
\hline
\end{tabular}

\section{Indirect capital cost}

$$
\begin{aligned}
& \text { Design and } \\
& \text { engineering }
\end{aligned}
$$

Contractor's fees

Contingency

allowance

Land
Total capital costs
$£ \mathrm{~m}$

$£ \mathrm{~m}$

$£ \mathrm{~m}$

$£ \mathrm{~m}$

$£ \mathrm{~m}$

$£ \mathrm{~m}$

Maintenance
Operating labour cost
Laboratory costs
Supervision

Plant overheads

Local taxes

Insurance rate

\section{Limestone}

Ni Catalyst

$\mathrm{Fe}_{2} \mathrm{O}_{3}$ oxygen

carriers

$\mathrm{CO}_{2}$ storage cost

Boiler feed water

Electricity
$£ \mathrm{~m}$

$£ \mathrm{~m}$

£m

$£ \mathrm{~m}$

$£ \mathrm{~m}$

$£ \mathrm{~m}$

$£ \mathrm{~m}$

$£ \mathrm{~m}$

$£ \mathrm{~m}$

$£ \mathrm{~m}$

$£ \mathrm{~m}$
28.5

7.1

7.1
37.6

9.4

9.4

Non-Depreciable Capital Costs

3.2

3.7

3.8

4.4

3.8

4.4

188.7

193.5

248.4

293.0

264.9

284.9

\section{Operating costs}

\section{Fixed operating costs}

$\begin{array}{llllll}18.9 & 19.4 & 24.8 & 29.3 & 26.5 & 28.5 \\ 1.82 & 1.82 & 1.82 & 1.82 & 1.82 & 1.82 \\ 0.36 & 0.36 & 0.36 & 0.36 & 0.36 & 0.36 \\ 0.18 & 0.18 & 0.18 & 0.18 & 0.18 & 0.18 \\ 1.09 & 1.09 & 1.09 & 1.09 & 1.09 & 1.09 \\ 1.89 & 1.93 & 2.48 & 2.93 & 2.65 & 2.85 \\ 1.89 & 1.93 & 2.48 & 2.93 & 2.65 & 2.85\end{array}$

Variable operating costs

$\begin{array}{llllll}0.13 & 0.13 & 0.13 & 0.13 & 0.13 & 0.13 \\ 0.54 & 0.54 & 0.54 & 0.54 & 0.54 & 0.54\end{array}$

0.00

0.00

0.00

0.00

0.69

1.30

19.0

19.0

28.3

36.7

36.7

37.1

3.14

3.24

3.14

3.14

3.46

$27.6 \quad 27.6$

61.9

73.4

36.2 


\begin{tabular}{|c|c|c|c|c|c|c|c|}
\hline $\begin{array}{c}\text { Miscellaneous } \\
\text { materials }\end{array}$ & $£ \mathrm{~m}$ & 1.82 & 2.16 & 2.43 & 3.25 & 2.31 & 2.49 \\
\hline \multicolumn{8}{|c|}{ Fuel costs } \\
\hline Natural gas & $£ \mathrm{~m}$ & 159.1 & 122.8 & 156.1 & 122.7 & 163.0 & 122.6 \\
\hline Biomass & $£ \mathrm{~m}$ & 0.0 & 51.1 & 0.0 & 51.7 & 0.0 & 53.1 \\
\hline Total operating costs & $£ \mathrm{~m}$ & 237.5 & 252.9 & 286.0 & 329.8 & 277.5 & 299.0 \\
\hline $\begin{array}{c}\mathrm{LCOH} \text { (without } \mathrm{CO}_{2} \\
\text { storage) }\end{array}$ & $£ / \mathrm{kg}$ & 1.78 & 2.04 & 2.12 & 2.58 & 2.03 & 2.31 \\
\hline $\begin{array}{c}\mathrm{LCOH} \text { (with } \mathrm{CO}_{2} \\
\text { storage) }\end{array}$ & $£ / \mathrm{kg}$ & 1.90 & 2.15 & 2.30 & 2.80 & 2.26 & 2.53 \\
\hline $\begin{array}{c}\text { Cost of } \mathrm{CO}_{2} \text { avoided } \\
\text { (zero carbon price) }\end{array}$ & $£ /$ tonne & 33.0 & 45.7 & 57.3 & 68.6 & 54.4 & 52.9 \\
\hline $\begin{array}{l}\text { Cost of } \mathrm{CO}_{2} \text { avoided } \\
\text { (with carbon price) }\end{array}$ & $£ /$ tonne & -24.7 & 0.3 & 10.6 & 36.2 & 7.7 & 20.8 \\
\hline $\begin{array}{c}\text { Cost of } \mathrm{CO}_{2} \text { removal } \\
\text { (zero carbon price) }\end{array}$ & $£ /$ tonne & 57.7 & 96.9 & 80.0 & 106.5 & 72.7 & 81.9 \\
\hline $\begin{array}{l}\text { Cost of } \mathrm{CO}_{2} \text { removal } \\
\text { (with carbon price } \\
£ 16 / \text { tonne } \mathrm{CO}_{2} \text { ) }\end{array}$ & $£ /$ tonne & -38.7 & 0.5 & 14.8 & 56.3 & 10.2 & 32.2 \\
\hline
\end{tabular}

Figure 4 shows the breakdown of total capital costs of different SE-SMR configurations. The direct capital costs of reformer and calciner are the major share of the SE-SMR process, accounting for $32 \%$ to $43 \%$ of the total capital costs for each case. The direct capital costs of PSA unit and heat exchangers serve as the second and third largest share of the total capital costs, which constitute values of $13 \%$ to $21 \%$ and $9 \%$ to $15 \%$ respectively.

The breakdown of variable operating costs of different SE-SMR hydrogen plants is shown in Figure 5. It can be concluded that the $\mathrm{CO}_{2}$ storage and electricity costs make up the majority of variable operating costs of different SE-SMR hydrogen plants (>88\%). Here Case 2A and 2B have the greatest share of electricity cost $(64.07 \%$ and $62.83 \%$ ), which is due to the installation of an ASU for oxygen production. Although there is a concern about the decay of the natural $\mathrm{CaO}$ sorbent during the $\mathrm{CO}_{2}$ capture process, the costs of limestone only contribute $0.11 \%$ to $0.25 \%$ to the total variable operating costs of different SE-SMR configurations based on the lifetime of $500 \mathrm{~h}$. Also, the end-use of lime-based sorbents from calcium looping process has been successfully proved for cement production[59], which offers the potential to offset the costs of limestone consumption during the SE-SMR process. 


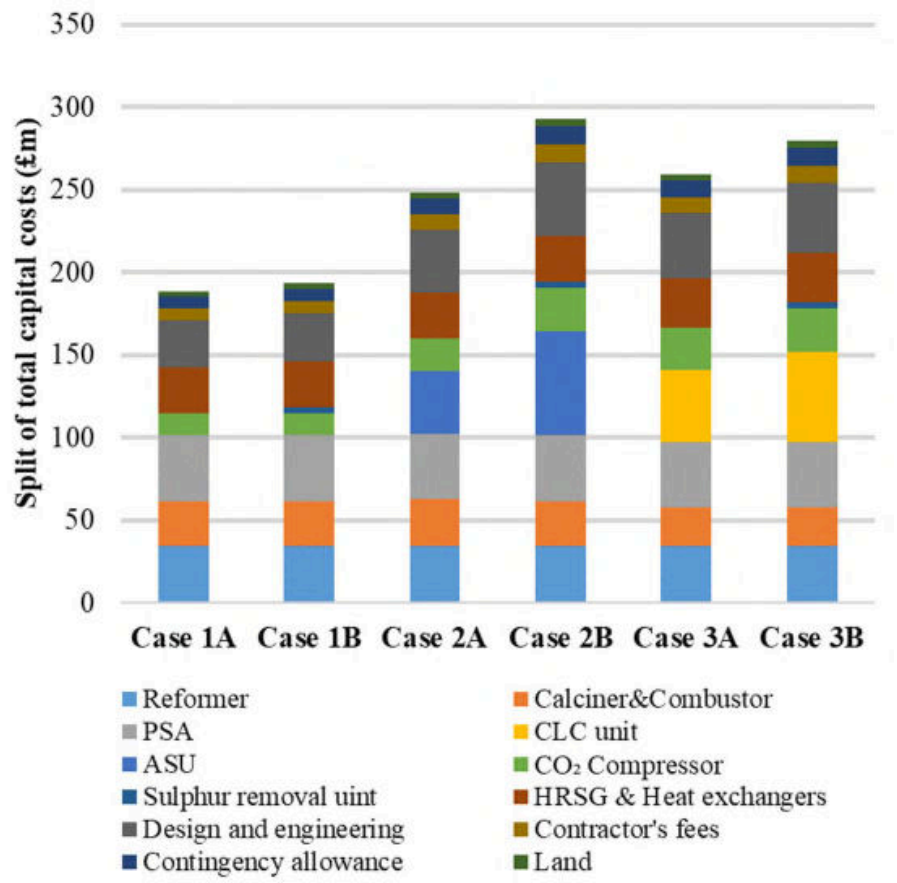

Figure 4 Split of total capital costs of SE-SMR hydrogen plants

Figure 6 presents the levelised cost of hydrogen (LCOH) and distribution of its different components of different SE-SMR hydrogen plants with $\mathrm{CO}_{2}$ transport and storage. Case 1A has the lowest $\mathrm{LCOH}$ ( $£ 1.90 / \mathrm{kg} \mathrm{H}_{2}$ ) among others but the lowest overall $\mathrm{CO}_{2}$ capture efficiency $(60.08 \%)$. The $\mathrm{LCOH}$ of Case $3 \mathrm{~A}$ is $£ 2.26 / \mathrm{kg} \mathrm{H}_{2}$, which is $18.95 \%$ points greater than that of Case $1 \mathrm{~A}$ and $5.12 \%$ points than that of Case $1 \mathrm{~B}$ but is the most economic pathway for nearly whole $\mathrm{CO}_{2}$ capture compared that of Case $2 \mathrm{~A}, 2 \mathrm{~B}$ and $3 \mathrm{~B}$ ( $2.30, £ 2.80$ and $£ 2.53 / \mathrm{kg} \mathrm{H}_{2}$ ). The LCOH of proposed SE-SMR processes in this study is comparable with the LCOH of SMR, ATR and coal with CCS ( $£ 1.76$ and $£ 2.08 / \mathrm{kg} \mathrm{H}_{2}$ ), and is more competitive than that of biomass with CCS ( $£ 2.8 / \mathrm{kg} \mathrm{H}_{2}$ ) and electrolysis with renewable energy ( $£ 6.38-11.55 / \mathrm{kg} \mathrm{H}_{2}$ ) [60]. 


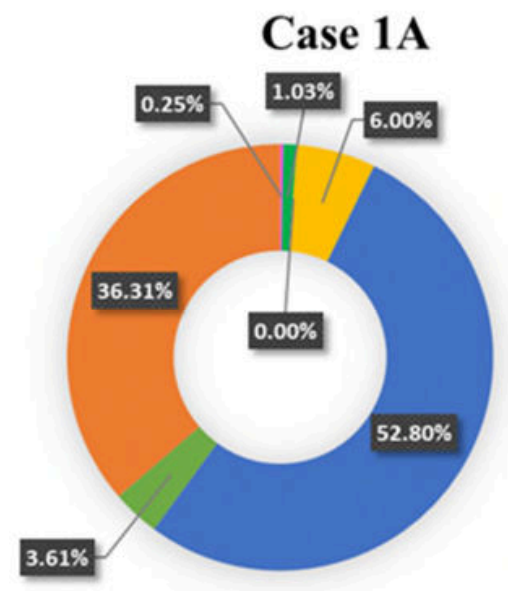

$=$ Limestone
Ni Catalyst
= Oxygen carriers
$=$ Water
$=$ Electricity
$=$ Miscellaneous
materials
$=$ CO

Case 2A

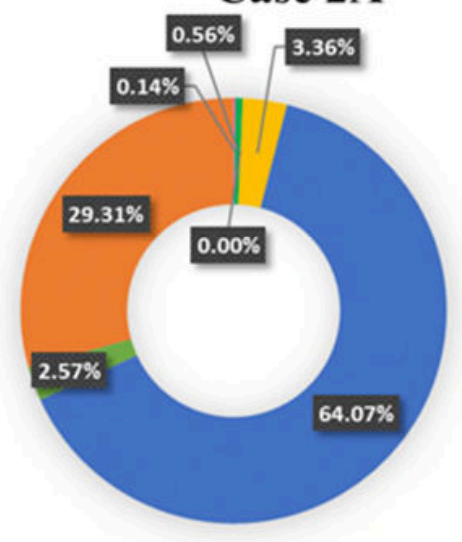

Eimestone

n Ni Catalyst

" Oxygen carriers

water

Electricity

= Miscellaneous

materials

= $\mathrm{CO}_{2}$ storage cost

\section{Case 3A}

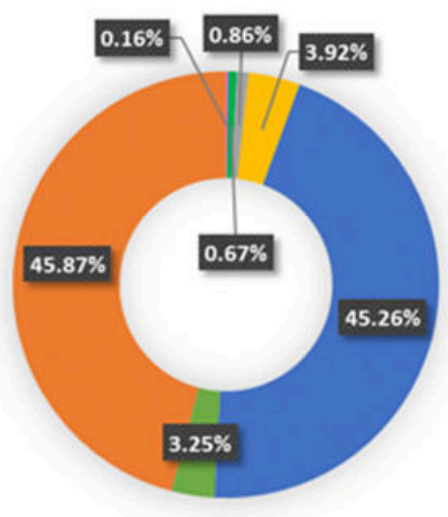

= Limestone

Ni Catalyst

m Oxygen carriers

w Water

Electricity

Miscellaneous materials

$=\mathrm{CO}_{2}$ storage cost
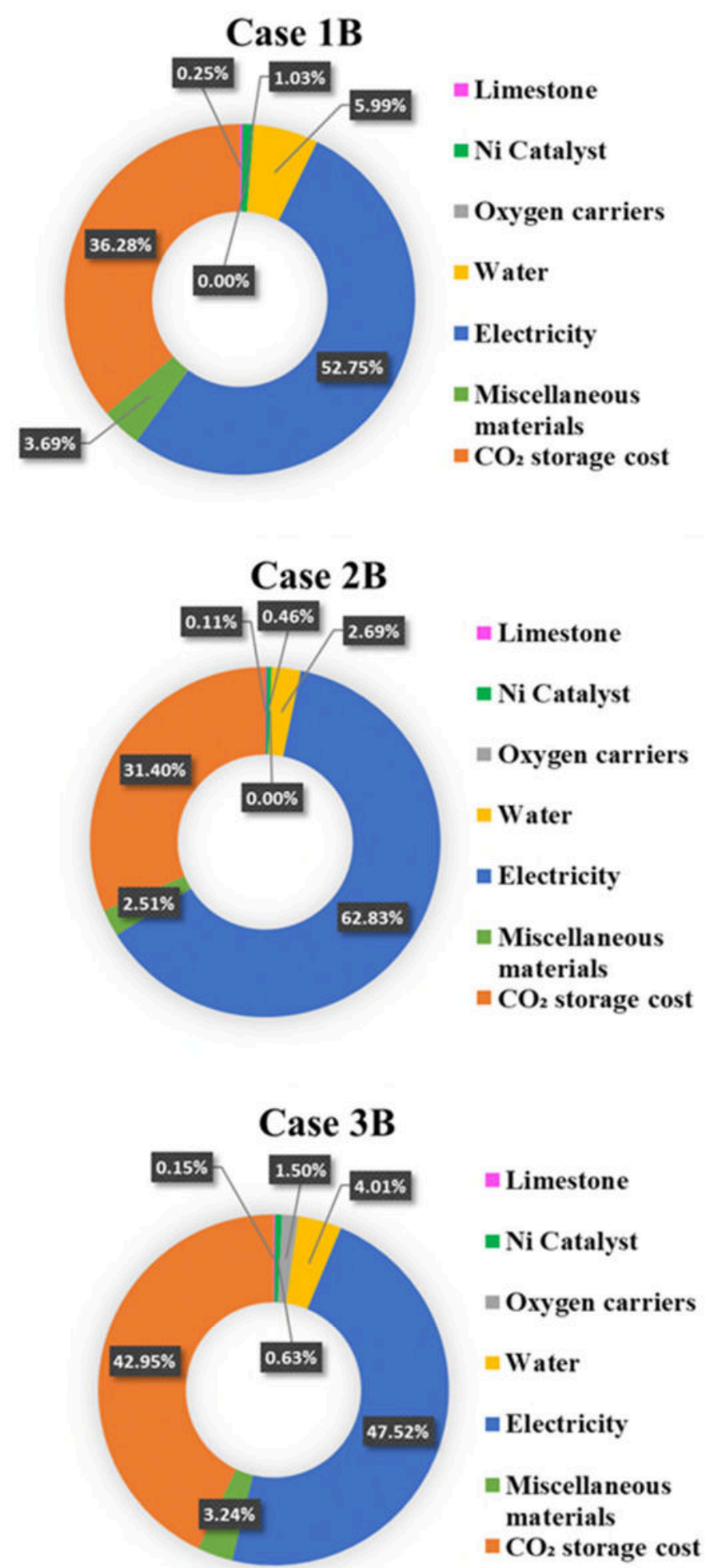

Figure 5 Split of the variable operating costs of SE-SMR hydrogen plants 


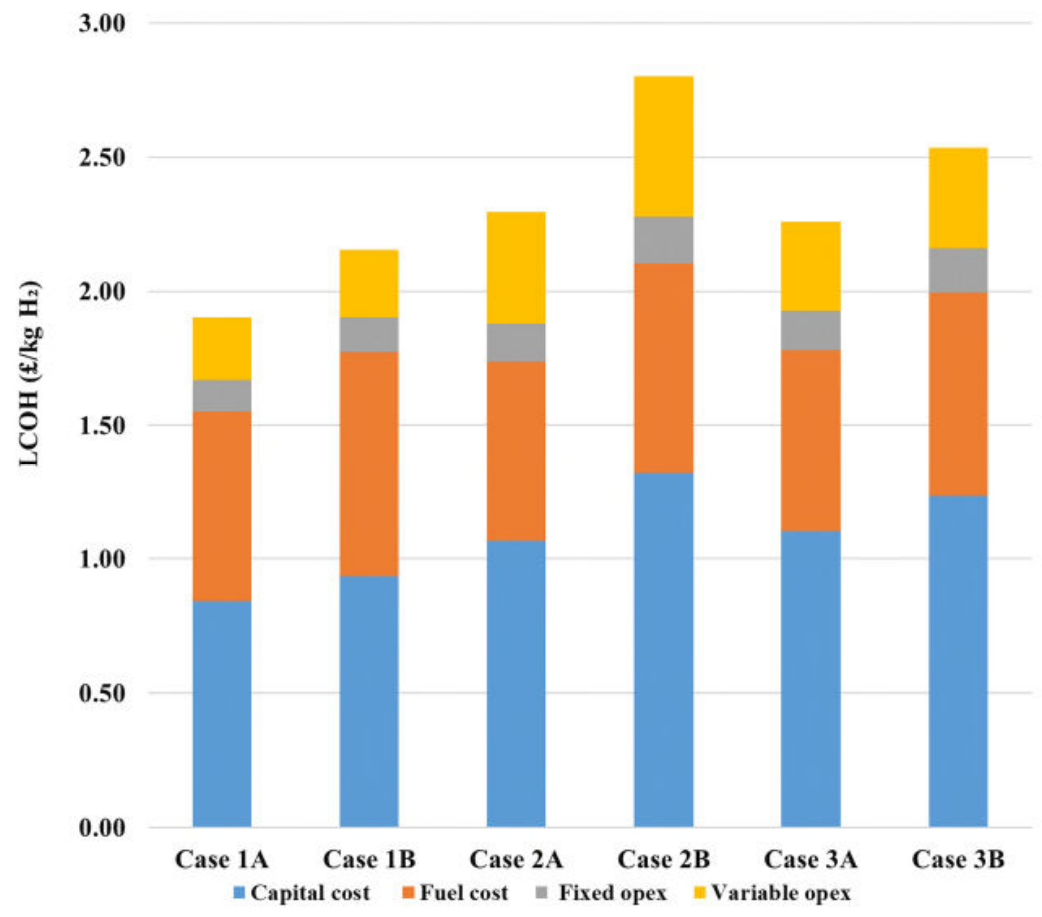

Figure 6 Distribution of different costs of levelised cost of hydrogen for different SE-SMR processes

The cost of $\mathrm{CO}_{2}$ avoided and removal of different SE-SMR processes with/without a carbon price are shown in Table 6. Interestingly, the cost of $\mathrm{CO}_{2}$ avoided and removal decreases dramatically by applying a carbon price of $£ 16 /$ tonne $\mathrm{CO}_{2}$. The calculated cost of $\mathrm{CO}_{2}$ avoided of different SE-SMR processes proposed in this work is in the range of $£ 32.97$ to $£ 68.55 /$ tonne $\mathrm{CO}_{2}$, which is lower than that of SMR with MDEA ( $£ 104.92 /$ tonne $\mathrm{CO}_{2}$ ), CLR (£78.10/tonne $\mathrm{CO}_{2}$ ) [25] and ATR ( $£ 64.31 /$ tonne $\mathrm{CO}_{2}$, excluding Case 2B) [26]. The estimated cost of $\mathrm{CO}_{2}$ removal for carbon-negative hydrogen production in the Case $2 \mathrm{~B}$ and $3 \mathrm{~B}$ is $£ 106.50 /$ tonne $\mathrm{CO}_{2}$ and $£ 81.91$ /tonne $\mathrm{CO}_{2}$ respectively, which is significantly lower than that of biomassderived hydrogen with carbon capture and storage (BHCCS)- $£ 149 /$ tonne $\mathrm{CO}_{2}$ reported in [61].

The costs of integration of SMR with CCS technologies have been extensively investigated over the past two decades. The cost of hydrogen from these studies varies from $£ 0.95-2.18 / \mathrm{kg} \mathrm{H}_{2}$ for capture rates from 60-90\%, and their cost of $\mathrm{CO}_{2}$ avoided ranges from $£ 13-106 /$ tonne $\mathrm{CO}_{2}$ [60]. Compared with the economic performance of the cases presented in this work, it can be concluded that the economic performance of different SE-SMR configurations proposed in this work is promising and comparable with that of currently available SMR with CCS technology. Furthermore, the Case $2 \mathrm{~B}$ and $3 \mathrm{~B}$ can achieve negative $\mathrm{CO}_{2}$ emissions from $\mathrm{H}_{2}$ production with a moderate $\mathrm{LCOH}\left(£ 2.80\right.$ and $£ 2.53 / \mathrm{kg} \mathrm{H}_{2}$ ) and cost of $\mathrm{CO}_{2}$ avoided 
( $£ 68.55$ and $£ 52.90 /$ tonne $\mathrm{CO}_{2}$ ). When the carbon price of $£ 16 /$ tonne $\mathrm{CO}_{2}$ is employed, it further reduces their cost of $\mathrm{CO}_{2}$ avoided to $£ 36.24$ and $£ 20.79$ /tonne $\mathrm{CO}_{2}$ respectively.

Notably, the estimated production cost of hydrogen from natural gas and cost of $\mathrm{CO}_{2}$ avoided are influenced by various technical and economic factors, for instance, the complexity and accuracy of the technoeconomic models and uncertainty of the input variables (e.g. natural gas price, capital costs of equipment, $\mathrm{CO}_{2}$ storage cost and carbon price). In the next section, the impacts of uncertainty in the input variables on the levelised cost of hydrogen for different SE-SMR configurations are discussed.

\subsubsection{Sensitivity analysis}

The $\mathrm{LCOH}$ is one of the key economic performance indicators for SE-SMR hydrogen plants, which is affected by different technical and economic factors. A sensitivity analysis including the effects of uncertainty in the total direct capital costs (TDCC), discount rate, fuel costs, $\mathrm{CO}_{2}$ storage cost, operating capacity factor and net efficiency on the LCOH of the different SE-SMR processes was conducted to investigate the economic performance of SE-SMR plants in the presence of uncertainty.

The SE-SMR processes are highly sensitive to the fuel costs as seen in Figure 7 (c). The reference price of natural gas and biomass is $£ 15.41 / \mathrm{MWh}$ and $£ 19.00 / \mathrm{MWh}$ respectively, and a change in their price by $\pm 30 \%$ points affects the LCOH for SE-SMR plants by an average of $-12.46-18.69 \%$ points. Due to the low TRL of the SE-SMR process and lack of published data on the capital cost of commercial scale SE-SMR hydrogen plant, $\pm 30 \%$ change is considered to investigate the impacts on the LCOH for different SE-SMR processes and the results are shown in Figure 7 (a). This changes the LCOH for SE-SMR plants by an average of $\pm 4.67 \%$ points compared that of reference cases.

Discount rates for low-carbon and renewable generation technologies are significantly influenced by the maturity of technology, systematic and policy risk. In this study, a discount rate of $12 \%$ has been applied to the base cases of SE-SMR processes, and it is reasonable to estimate it will fluctuate in the range of 6 to $14 \%$ according to [42]. Figure 7 (b) illustrates the increase of discount rate from $6 \%$ to $14 \%$ rises the LCOH of SE-SMR processes by an average of $3.58 \%$ points. $\mathrm{A} \pm 30 \%$ change in the $\mathrm{CO}_{2}$ storage cost in the base cases acts the average of $-1.54 \%$ to $2.31 \%$ points on the $\mathrm{LCOH}$ of base SE-SMR processes as Figure 7 (d) shown. The increase of operating capacity factor from $80 \%$ to $100 \%$ reduces the LCOH by an average of $3.83 \%$ points (Figure 7 (e)). In the Figure 7 (d), when the net efficiency of base cases decreases by $10 \%$ points, the $\mathrm{LCOH}$ rises by an average of $6.92 \%$ points. On the other hand, with an increase of the net efficiency in the base cases by $10 \%$ points, the $\mathrm{LCOH}$ declines by an average of $5.66 \%$. 
Based on the sensitivity analysis, it is clear that the economic performance of SE-SMR processes proposed in this work is mainly affected by the fuel costs of natural gas and biomass, followed by the net efficiency, TDCC, discount rate and $\mathrm{CO}_{2}$ storage cost. This generally agrees well with other techno-economic assessment work on SMR with/without CCS or SE-SMR for hydrogen production in [1,17].
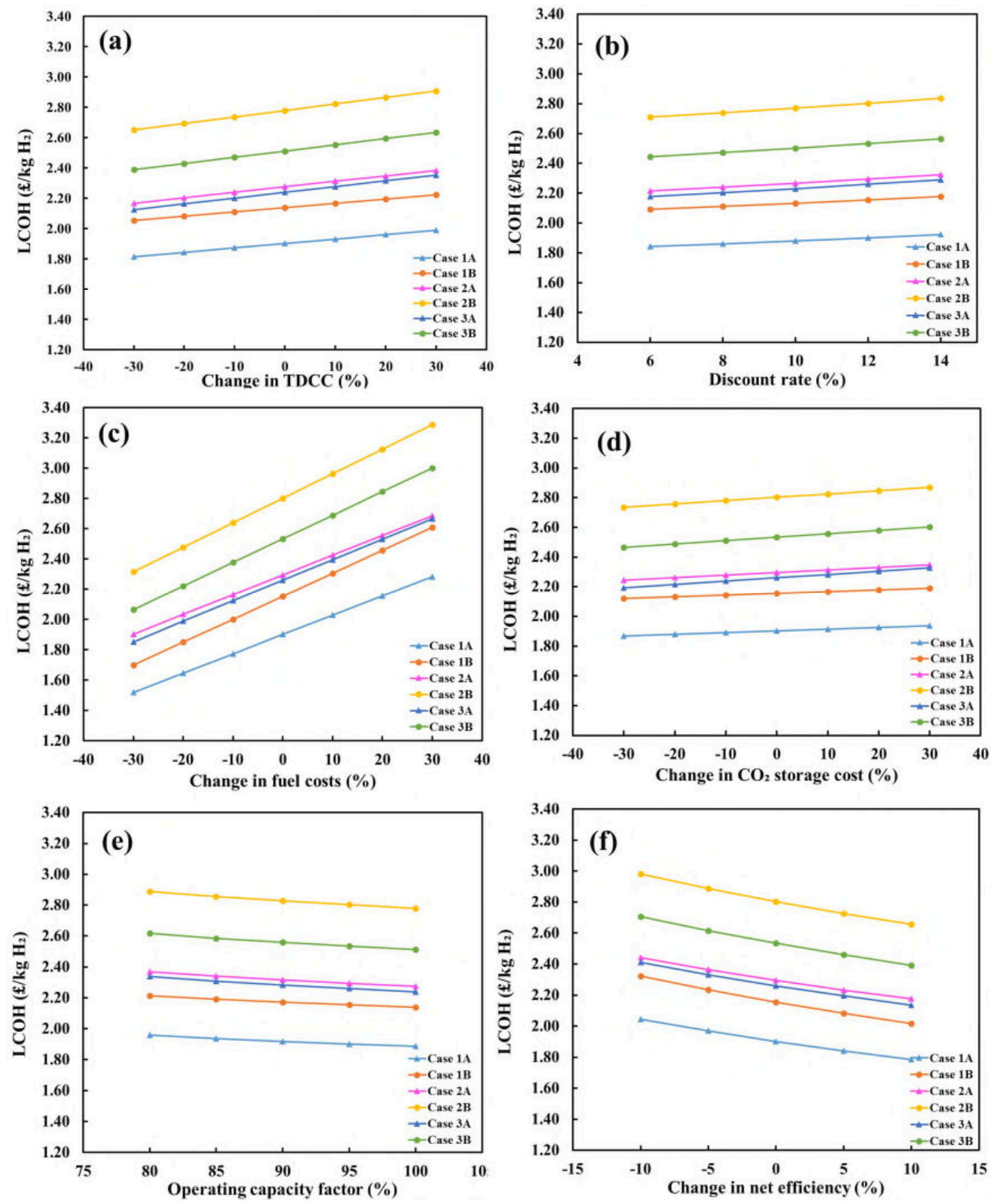

Figure 7 Sensitivity analyses a) TDCC vs LCOH, b) Discount rate vs $\mathrm{LCOH}$, c) Fuel costs vs LCOH, d)

$\mathrm{CO}_{2}$ storage costs vs $\mathrm{LCOH}$, e) Operating capacity factor vs $\mathrm{LCOH}$, f) Net efficiency vs LCOH. 
Discounted cash flow analysis is an important technique for translating the net future cash flows of the project to the net present value (NPV), which gives a clear indication of the resources required for a project and the timing of earning. Figure 8 presents the cumulative discounted cash flow of proposed SE-SMR processes in this work with hydrogen selling price of $£ 2.20$, 22.60 and $£ 3.00 / \mathrm{kg} \mathrm{H} \mathrm{H}_{2}$. Here Case $2 \mathrm{~B}$ and 3B cannot make any revenue when the hydrogen selling price is assumed to be less than $£ 2.20 / \mathrm{kg}$. When the hydrogen price is increased from $£ 2.20 / \mathrm{kg}$ to $£ 2.60 / \mathrm{kg}$, all the proposed SE-SMR processes can make profits after the $13^{\text {th }}$ year of the project. At a hydrogen selling price of $£ 3.00 / \mathrm{kg}$, the payback time of Case $1 \mathrm{~A}$ and $1 \mathrm{~B}$ is 5 years, followed by 6 years for Case $2 \mathrm{~A}$ and $3 \mathrm{~A}, 7$ years for Case $3 \mathrm{~B}$, and 8 years for Case $2 \mathrm{~B}$.

Notably, the hydrogen selling price play a crucial role in the economic performance of hydrogen production plants. Although the current hydrogen selling price is approximately $£ 7.50 / \mathrm{kg} \mathrm{H}_{2}$ at hydrogen vehicle refuelling stations in the UK [62] and the transaction prices of hydrogen are in the range of $£ 1.40 / \mathrm{kg}$ to $£ 3.60 / \mathrm{kg}$ in terms of scale and purity[63], the proposed SE-SMR processes in this study shows that blue and carbon negative hydrogen are able to achieve significant economic gains with a hydrogen selling price of only from $£ 2.20$ to $3.00 / \mathrm{kg} \mathrm{H}_{2}$.
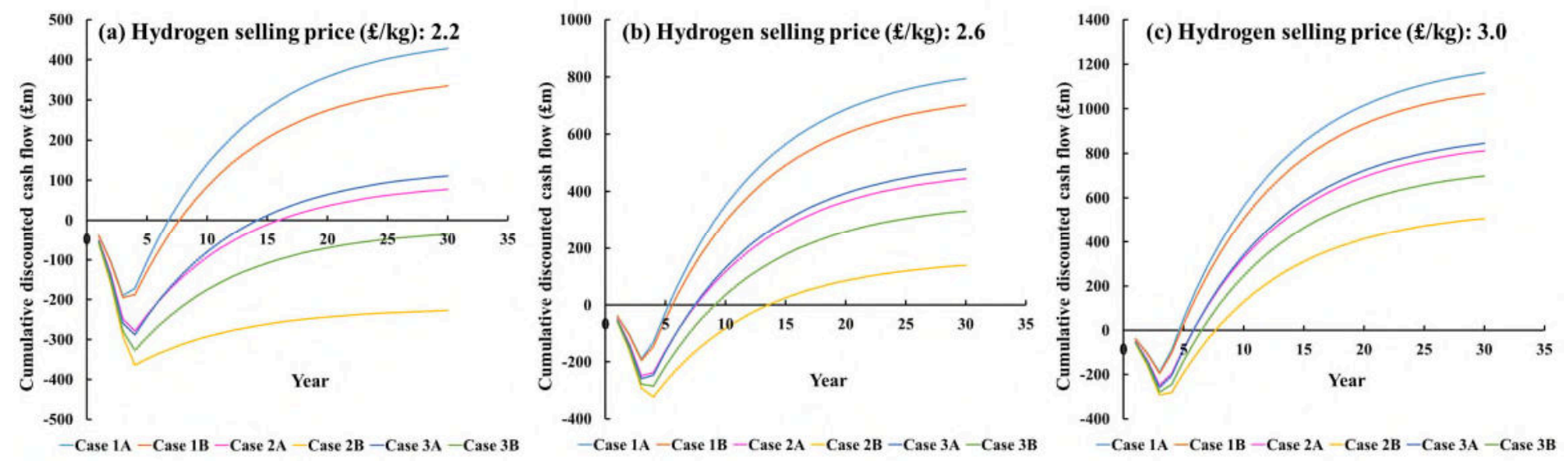

Figure 8 Cumulative discounted cash flow of SE-SMR plants under different hydrogen selling price

\section{Conclusions}

This work presents a detailed techno-economic assessment of six SE-SMR configurations for large-scale blue and carbon-negative hydrogen production. The impact of incorporating oxy-fuel combustion, chemical-looping combustion and $\mathrm{CO}_{2}$ compression unit, and using biomass as the feedstock for providing combustion heat to the calciner on the net efficiency, $\mathrm{CO}_{2}$ capture efficiency, levelised cost of hydrogen, $\mathrm{CO}_{2}$ avoided and removal cost of the proposed cases were also evaluated. Results indicated that the retrofitted SE-SMR processes could provide flexible options for low-carbon hydrogen production based on the costs and demand of $\mathrm{CO}_{2}$ reduction and were comparable with SMR with CCS technologies. 
The replacement of natural gas by biomass in the calciner has improved the $\mathrm{CO}_{2}$ captured for all the cases, but reduced their net efficiency by an average of $8.25 \%$ points. SE-SMR with indirect air-natural gas combustion calciner (Case 1A) has the highest net efficiency (76.96\%) and the lowest LCOH (£1.90/kg $\mathrm{H}_{2}$ ), but only $60.06 \% \mathrm{CO}_{2}$ is captured. The replacement of natural gas by biomass in the calciner (Case $1 \mathrm{~B}$ ) can increase the $\mathrm{CO}_{2}$ capture efficiency to $86.08 \%$ with the $\mathrm{LCOH}$ of $£ 2.15 / \mathrm{kg} \mathrm{H}_{2}$. In Case $2 \mathrm{~A}$ (SE-SMR with indirect oxy-natural gas combustion calciner) and Case 3A (SE-SMR with indirect calciner heated by chemical-looping combustion with natural gas) can realise almost complete $\mathrm{CO}_{2}$ capture and pure hydrogen production, but Case $3 \mathrm{~A}$ is more economically favourable than Case $2 \mathrm{~A}$ in terms of $\mathrm{LCOH}$ and costs of $\mathrm{CO}_{2}$ avoided and removal. With the use of biomass in Case $2 \mathrm{~B}$ and Case 3B, this can achieve carbonnegative hydrogen production, which removes $5.42 \mathrm{~kg}$ and $5.52 \mathrm{~kg}$ of $\mathrm{CO}_{2}$ respectively from the atmosphere per kg hydrogen produced but with the highest $\mathrm{LCOH}$ and costs of $\mathrm{CO}_{2}$ avoided and removal. By applying a carbon price ( $£ 16 /$ tonne $\mathrm{CO}_{2}$ ) it is possible to reduce the costs of $\mathrm{CO}_{2}$ avoided and removal significantly. The results of sensitivity analyses indicated that fuel costs of natural gas and biomass are the major factor affecting the economic performance of proposed SE-SMR processes, followed by net efficiency, total direct capital costs of equipment and $\mathrm{CO}_{2}$ storage costs. Cumulative discounted cash flow of the proposed SESMR plants with hydrogen selling price from $£ 2.20-3.00$ was calculated to analyse the profitability and payback time. With a hydrogen selling price of $£ 3.00 / \mathrm{kg}$, investment in any of the proposed SE-SMR plants can be paid back after eight years without employing a carbon price.

\section{Acknowledgments}

YYL would like to acknowledge the financial support from the Cranfield University Energy and Power research bursary.

\section{References}

[1] IEA. The Future of Hydrogen. 2019. doi:10.1787/1e0514c4-en.

[2] Voldsund M, Jordal K, Anantharaman R. Hydrogen production with $\mathrm{CO}_{2}$ capture. Int J Hydrogen Energy 2016;41:4969-92. doi:10.1016/j.ijhydene.2016.01.009.

[3] Ji G, Yao JG, Clough PT, Da Costa JCD, Anthony EJ, Fennell PS, et al. Enhanced hydrogen production from thermochemical processes. Energy Environ Sci 2018;11:2647-72. doi:10.1039/c8ee01393d.

[4] Muradov N. Low to near-zero $\mathrm{CO}_{2}$ production of hydrogen from fossil fuels: Status and 
perspectives. Int J Hydrogen Energy 2017;42:14058-88. doi:10.1016/j.ijhydene.2017.04.101.

[5] Cormos CC, Petrescu L, Cormos AM. Assessment of hydrogen production systems based on natural gas conversion with carbon capture and storage. Comput. Aided Chem. Eng., vol. 33, Elsevier B.V.; 2014, p. 1081-6. doi:10.1016/B978-0-444-63455-9.50015-5.

[6] Johnsen K, Ryu HJ, Grace JR, Lim CJ. Sorption-enhanced steam reforming of methane in a fluidized bed reactor with dolomite as $\mathrm{CO}_{2}$-acceptor. Chem Eng Sci 2006;61:1195-202. doi:10.1016/j.ces.2005.08.022.

[7] García-Lario AL, Aznar M, Martinez I, Grasa GS, Murillo R. Experimental study of the application of a $\mathrm{NiO} / \mathrm{NiAl}_{2} \mathrm{O}_{4}$ catalyst and a CaO-based synthetic sorbent on the Sorption Enhanced Reforming process. Int J Hydrogen Energy 2015;40:219-32. doi:10.1016/j.ijhydene.2014.10.033.

[8] Arstad B, Prostak J, Blom R. Continuous hydrogen production by sorption enhanced steam methane reforming (SE-SMR) in a circulating fluidized bed reactor: Sorbent to catalyst ratio dependencies. Chem Eng J 2012;189-190:413-21. doi:10.1016/j.cej.2012.02.057.

[9] Di Giuliano A, Gallucci K, Kazi SS, Giancaterino F, Di Carlo A, Courson C, et al. Development of $\mathrm{Ni}$ - and $\mathrm{CaO}-$ based mono- and bi-functional catalyst and sorbent materials for Sorption Enhanced Steam Methane Reforming: Performance over 200 cycles and attrition tests. Fuel Process Technol 2019;195:106160. doi:10.1016/j.fuproc.2019.106160.

[10] Broda M, Manovic V, Imtiaz Q, Kierzkowska AM, Anthony EJ, Müller CR. High-purity hydrogen via the sorption-enhanced steam methane reforming reaction over a synthetic CaO-based sorbent and a Ni catalyst. Environ Sci Technol 2013;47:6007-14. doi:10.1021/es305113p. 
[11] Chen J, Donat F, Duan L, Kierzkowska AM, Min Kim S, Xu Y, et al. Metal-oxide stabilized $\mathrm{CaO} / \mathrm{CuO}$ Composites for the Integrated $\mathrm{Ca} / \mathrm{Cu}$ Looping Process. Chem Eng $\mathrm{J}$ 2020;403:126330. doi:10.1016/j.cej.2020.126330.

[12] Rusten HK, Ochoa-Fernández E, Lindborg H, Chen D, Jakobsen HA. Hydrogen production by sorption-enhanced steam methane reforming using lithium oxides as $\mathrm{CO}_{2}$-acceptor. Ind Eng Chem Res 2007;46:8729-37. doi:10.1021/ie070770k.

[13] Ochoa-Fernández E, Haugen G, Zhao T, Rønning M, Aartun I, Børresen B, et al. Process design simulation of $\mathrm{H}_{2}$ production by sorption enhanced steam methane reforming: Evaluation of potential $\mathrm{CO}_{2}$ acceptors. Green Chem., vol. 9, Royal Society of Chemistry; 2007, p. 654-62. doi:10.1039/b614270b.

[14] Zhu L, Li L, Fan J. A modified process for overcoming the drawbacks of conventional steam methane reforming for hydrogen production: Thermodynamic investigation. Chem Eng Res Des 2015;104:792-806. doi:10.1016/j.cherd.2015.10.022.

[15] Alam S, Kumar JP, Rani KY, Sumana C. Self-sustained process scheme for high purity hydrogen production using sorption enhanced steam methane reforming coupled with chemical looping combustion. J Clean Prod 2017;162:687-701. doi:10.1016/j.jclepro.2017.05.136.

[16] Abanades JC, Murillo R, Fernandez JR, Grasa G, Martínez I. New $\mathrm{CO}_{2}$ capture process for hydrogen production combining $\mathrm{Ca}$ and $\mathrm{Cu}$ chemical loops. Environ Sci Technol 2010;44:6901-4. doi:10.1021/es101707t.

[17] Diglio G, Hanak DP, Bareschino P, Mancusi E, Pepe F, Montagnaro F, et al. Technoeconomic analysis of sorption-enhanced steam methane reforming in a fixed bed reactor network integrated with fuel cell. J Power Sources 2017;364:41-51. 
doi:10.1016/j.jpowsour.2017.08.005.

[18] Yan Y, Thanganadar D, Clough PT, Mukherjee S, Patchigolla K, Manovic V, et al. Process simulations of blue hydrogen production by upgraded sorption enhanced steam methane reforming (SE-SMR) processes. Energy Convers Manag 2020;222:113144. doi:10.1016/j.enconman.2020.113144.

[19] Antzara A, Heracleous E, Lemonidou AA. Energy efficient sorption enhanced-chemical looping methane reforming process for high-purity $\mathrm{H}_{2}$ production: Experimental proof-ofconcept. Appl Energy 2016;180:457-71. doi:10.1016/j.apenergy.2016.08.005.

[20] Martini M, van den Berg A, Gallucci F, van Sint Annaland M. Investigation of the process operability windows for $\mathrm{Ca}-\mathrm{Cu}$ looping for hydrogen production with $\mathrm{CO}_{2}$ capture. Chem Eng J 2016;303:73-88. doi:10.1016/j.cej.2016.05.135.

[21] Fernandez JR, Abanades JC, Grasa G. Modeling of sorption enhanced steam methane reforming-Part II: Simulation within a novel $\mathrm{Ca} / \mathrm{Cu}$ chemical loop process for hydrogen production. Chem Eng Sci 2012;84:12-20. doi:10.1016/j.ces.2012.07.050.

[22] Reitza M, Junka M, Ströhlea J, Epplea B. Design and erection of a 300 kWth indirectly heated carbonate looping test facility. Energy Procedia, vol. 63, Elsevier Ltd; 2014, p. 21707. doi:10.1016/j.egypro.2014.11.236.

[23] Reitz M, Junk M, Ströhle J, Epple B. Design and operation of a 300 kWth indirectly heated carbonate looping pilot plant. Int J Greenh Gas Control 2016;54:272-81. doi:10.1016/j.ijggc.2016.09.016.

[24] Junk M, Reitz M, Strohle J, Epple B. Technical and economical assessment of the indirectly heated carbonate looping process. J Energy Resour Technol Trans ASME 2016;138. doi:10.1115/1.4033142. 
[25] Spallina V, Shams A, Battistella A, Gallucci F, Annaland MVS. Chemical Looping Technologies for $\mathrm{H}_{2}$ Production with $\mathrm{CO}_{2}$ Capture: Thermodynamic Assessment and Economic Comparison. Energy Procedia, vol. 114, Elsevier Ltd; 2017, p. 419-28. doi:10.1016/j.egypro.2017.03.1184.

[26] Khojasteh Salkuyeh Y, Saville BA, MacLean HL. Techno-economic analysis and life cycle assessment of hydrogen production from natural gas using current and emerging technologies. Int J Hydrogen Energy 2017;42:18894-909. doi:10.1016/j.ijhydene.2017.05.219.

[27] Hafizi A, Rahimpour MR, Hassanajili S. Hydrogen production via chemical looping steam methane reforming process: Effect of cerium and calcium promoters on the performance of $\mathrm{Fe}_{2} \mathrm{O}_{3} / \mathrm{Al}_{2} \mathrm{O}_{3}$ oxygen carrier. Appl Energy 2016;165:685-94. doi:10.1016/j.apenergy.2015.12.100.

[28] Spallina V, Pandolfo D, Battistella A, Romano MC, Van Sint Annaland M, Gallucci F. Techno-economic assessment of membrane assisted fluidized bed reactors for pure $\mathrm{H}_{2}$ production with $\mathrm{CO}_{2}$ capture. Energy Convers Manag 2016;120:257-73. doi:10.1016/j.enconman.2016.04.073.

[29] Nazir SM, Cloete JH, Cloete S, Amini S. Pathways to low-cost clean hydrogen production with gas switching reforming. Int J Hydrogen Energy 2020. doi:10.1016/j.ijhydene.2020.01.234.

[30] Yan Y, Clough PT, Anthony EJ. Investigation of the apparent kinetics of air and oxy-fuel biomass combustion in a spout fluidised-bed reactor. Chem Eng Res Des 2020;153:276-83. doi:10.1016/j.cherd.2019.10.043.

[31] Aspen Technology. Aspen Physical Property Methods. 2013. 
[32] Ortiz M, Gayán P, De Diego LF, García-Labiano F, Abad A, Pans MA, et al. Hydrogen production with $\mathrm{CO}_{2}$ capture by coupling steam reforming of methane and chemical-looping combustion: Use of an iron-based waste product as oxygen carrier burning a PSA tail gas. J. Power Sources, vol. 196, Elsevier; 2011, p. 4370-81. doi:10.1016/j.jpowsour.2010.09.101.

[33] Aspen Plus: Getting Started Modeling Processes with Solids 2009:1-96.

[34] Tranier J-P, Dubettier R, Perrin N, Air Liquide. Air Separation Unit for Oxy-Coal Combustion Systems. 1st Int. Oxyfuel Combust. Conf., 2009.

[35] Wall T, Liu Y, Spero C, Elliott L, Khare S, Rathnam R, et al. An overview on oxyfuel coal combustion-State of the art research and technology development. Chem Eng Res Des 2009;87:1003-16. doi:10.1016/j.cherd.2009.02.005.

[36] Pei X, He B, Yan L, Wang C, Song W, Song J. Process simulation of oxy-fuel combustion for a $300 \mathrm{MW}$ pulverized coal-fired power plant using Aspen Plus. Energy Convers Manag 2013;76:581-7. doi:10.1016/j.enconman.2013.08.007.

[37] Fuels - Higher and Lower Calorific Values n.d. https://www.engineeringtoolbox.com/fuelshigher-calorific-values-d_169.html (accessed September 28, 2020).

[38] Typical calorific values of fuels - Forest Research. https://www.forestresearch.gov.uk/toolsand-resources/biomass-energy-resources/reference-biomass/facts-figures/typical-calorificvalues-of-fuels/

[39] Denys F, De Vries W. Gas Composition Transition Agency Report 2013 The status of the transition to high-calorific-value gas Date 1 August 2013 Status Final for publication. n.d.

[40] Sinnott RK. Costing and Project Evaluation. Coulson Richardson's Chem. Eng., 1993, p. 209-44. doi:10.1016/b978-0-08-041865-0.50014-3. 
[41] Cormos CC. Economic evaluations of coal-based combustion and gasification power plants with post-combustion $\mathrm{CO}_{2}$ capture using calcium looping cycle. Energy 2014;78:665-73. doi:10.1016/j.energy.2014.10.054.

[42] Oxera. Discount rates for low-carbon and renewable generation technologies Prepared for the Committee on Climate Change. 2011.

[43] HM Revenue \& Customs. Policy paper: Carbon Emissions Tax. Policy Pap 2018. https://www.gov.uk/government/publications/carbon-emmisions-tax/carbon-emmisions$\operatorname{tax}$.

[44] Kew Projects Ltd. Kew $\mathrm{H}_{2}$ : Zero-carbon bulk supply. 2019.

[45] MacKenzie A, Granatstein DL, Anthony EJ, Abanades JC. Economics of $\mathrm{CO}_{2}$ capture using the calcium cycle with a pressurized fluidized bed combustor. Energy and Fuels 2007;21:920-6. doi:10.1021/ef0603378.

[46] Porrazzo R, White G, Ocone R. Techno-economic investigation of a chemical looping combustion based power plant 2016. doi:10.1039/c6fd00033a.

[47] Nadir M, Ghenaiet A, Carcasci C. Thermo-economic optimization of heat recovery steam generator for a range of gas turbine exhaust temperatures. Appl Therm Eng 2016;106:81126. doi:10.1016/j.applthermaleng.2016.06.035.

[48] Porter RTJ, Fairweather M, Kolster C, Dowell N Mac, Shah N, Woolley RM. Cost and performance of some carbon capture technology options for producing different quality $\mathrm{CO}_{2}$ product streams.

[49] Maas W. The post-2020 Cost-Competitiveness of CCS Cost of Storage.

[50] Wood. Hydrogen Supply Programme - Novel Steam Methane / Gas Heated Reformer 2020:1-22. 
[51] United Kingdom electricity prices, September 2019 | GlobalPetrolPrices.com n.d. https://www.globalpetrolprices.com/United-Kingdom/electricity_prices/ (accessed June $12,2020)$.

[52] Standard rates | Anglian Water Services n.d. https://www.anglianwater.co.uk/account-andbill/tariffs-and-charges/standard-rates/ (accessed June 12, 2020).

[53] Nickel Catalyst / Z111 Series Primary Steam-reforming Catalysts - Buy Nickel Catalyst,Primary Steam-reforming Catalysts,Nickel Catalyst Manufacturer Product on Alibaba.com n.d. https://www.alibaba.com/product-detail/Nickel-catalyst-Z111-seriesprimary steam_62339979053.html?spm=a2700.galleryofferlist.0.0.11215a45D0GM56\&bypass=tr ue (accessed June 12, 2020).

[54] Longcliffe n.d. https://www.longcliffe.co.uk/ (accessed June 12, 2020).

[55] Diego ME, Arias B, Abanades JC. Modeling the solids circulation rates and solids inventories of an interconnected circulating fluidized bed reactor system for $\mathrm{CO}_{2}$ capture by calcium looping. Chem Eng J 2012;198-199:228-35. doi:10.1016/j.cej.2012.05.099.

[56] Lyngfelt A, Leckner B. A 1000 MWth boiler for chemical-looping combustion of solid fuels - Discussion of design and costs. Appl Energy 2015;157:475-87. doi:10.1016/j.apenergy.2015.04.057.

[57] Land Value Estimates for Policy Appraisal : May 2017 Values.

[58] 2019 Chemical Engineering Plant Cost Index Annual Average - Chemical Engineering | Page 1. https://www.chemengonline.com/2019-chemical-engineering-plant-cost-indexannual-average/ (accessed June 12, 2020).

[59] Erans M, Jeremias M, Zheng L, Yao JG, Blamey J, Manovic V, et al. Pilot testing of 
enhanced sorbents for calcium looping with cement production. Appl Energy 2018;225:392-401. doi:10.1016/j.apenergy.2018.05.039.

[60] Parkinson B, Balcombe P, Speirs JF, Hawkes AD, Hellgardt K. Levelized cost of $\mathrm{CO}_{2}$ mitigation from hydrogen production routes. Energy Environ Sci 2019;12:19-40. doi:10.1039/c8ee02079e.

[61] Bui M, Fajardy M, Zhang D, Mac Dowell N. Delivering negative emissions from biomass derived hydrogen 2020:1-81.

[62] LONDON: a capital for hydrogen and fuel cell technologies. 2016.

[63] Glenk G, Reichelstein S. Economics of converting renewable power to hydrogen. Nat Energy 2019;4:216-22. doi:10.1038/s41560-019-0326-1. 